Supporting Information

\title{
Progress toward the Total Synthesis of Goniodomin A: Stereocontrolled, Convergent Synthesis of the C12-C36 Fragment
}

Haruhiko Fuwa,* Seiji Matsukida, Taro Miyoshi, Yuki Kawashima, Tomoyuki Saito, and Makoto Sasaki*

Graduate School of Life Sciences, Tohoku University, 2-1-1 Katahira, Aoba-ku, Sendai 980-8577, Japan

Email: hfuwa@m.tohoku.ac.jp 

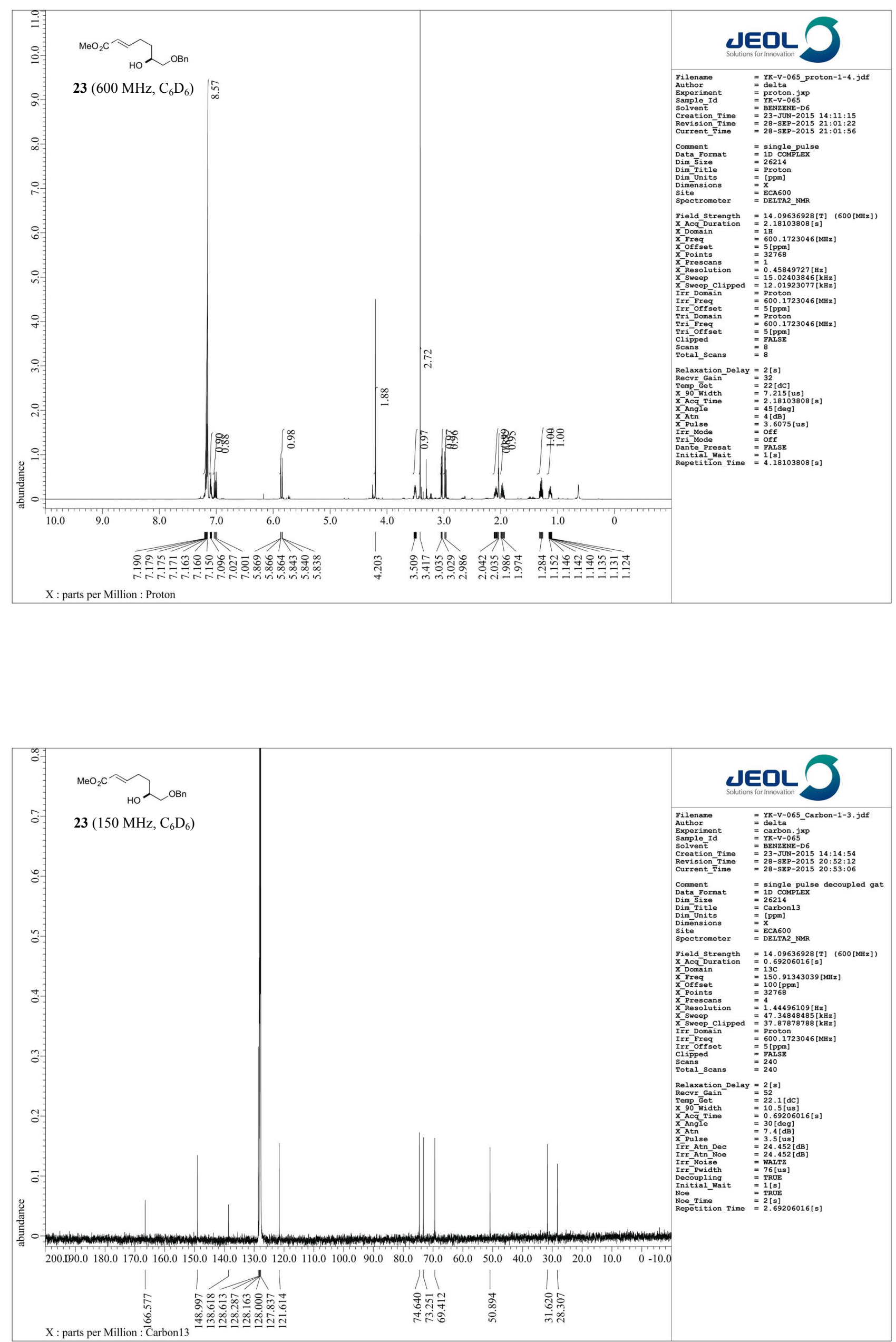

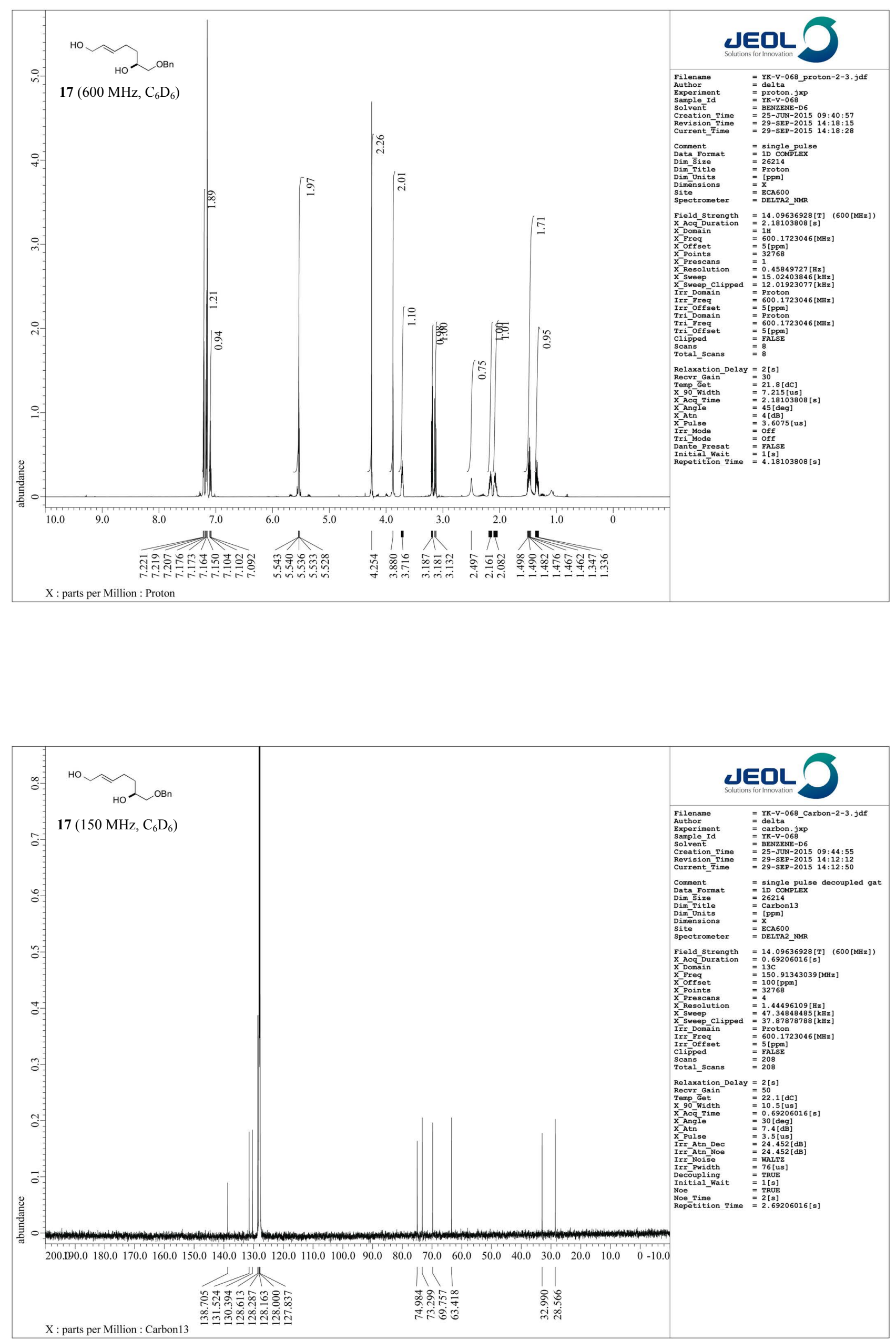

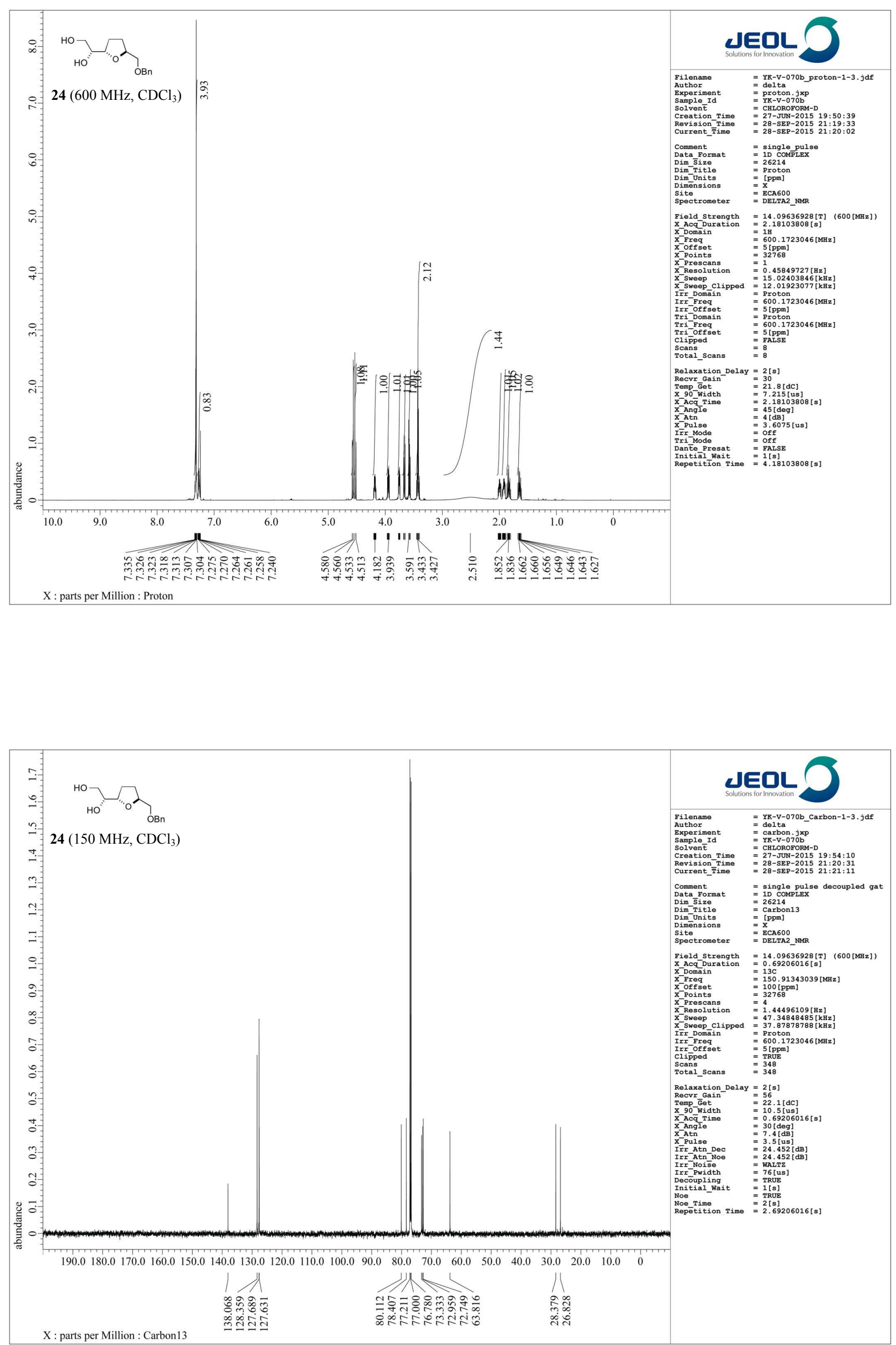

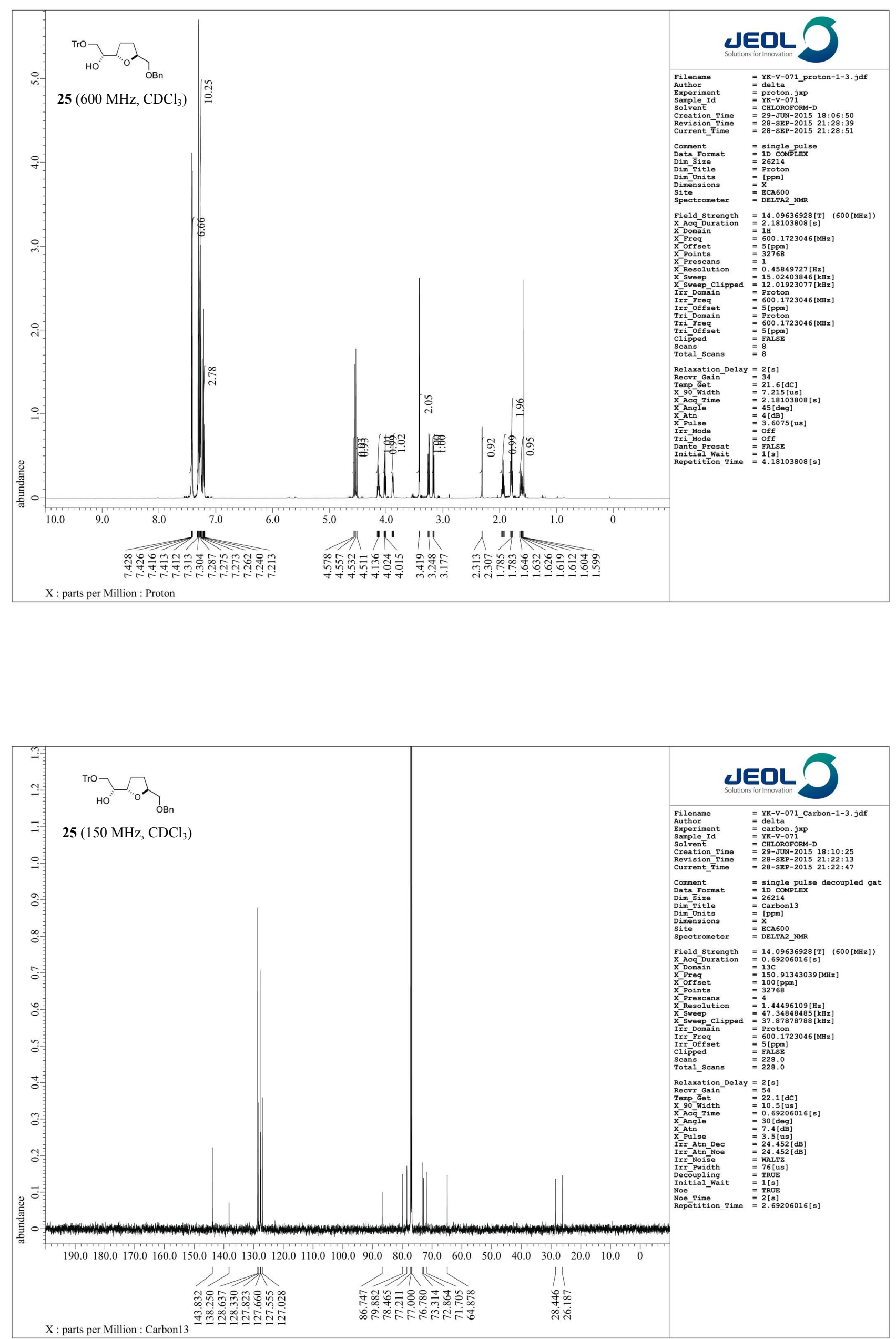

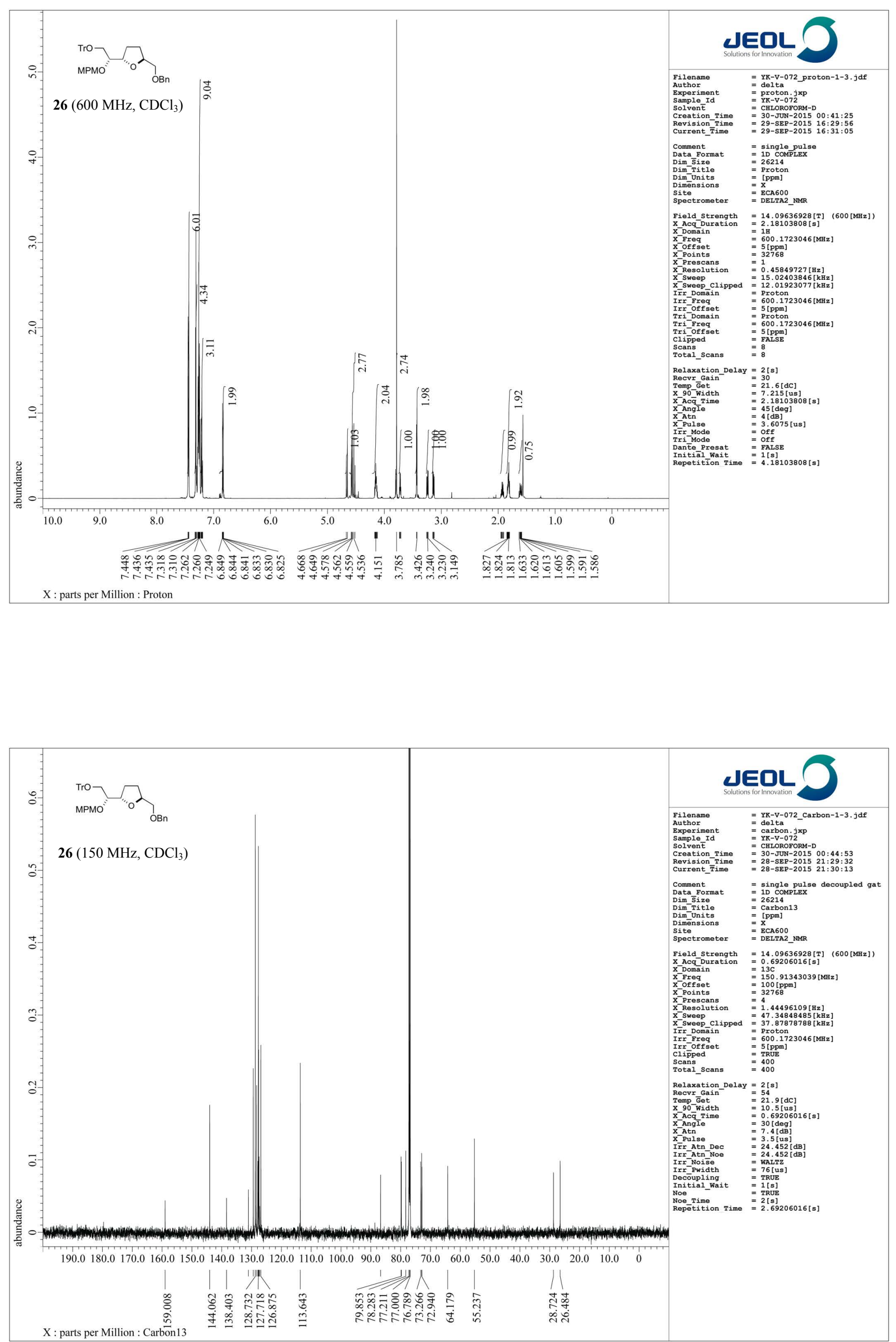

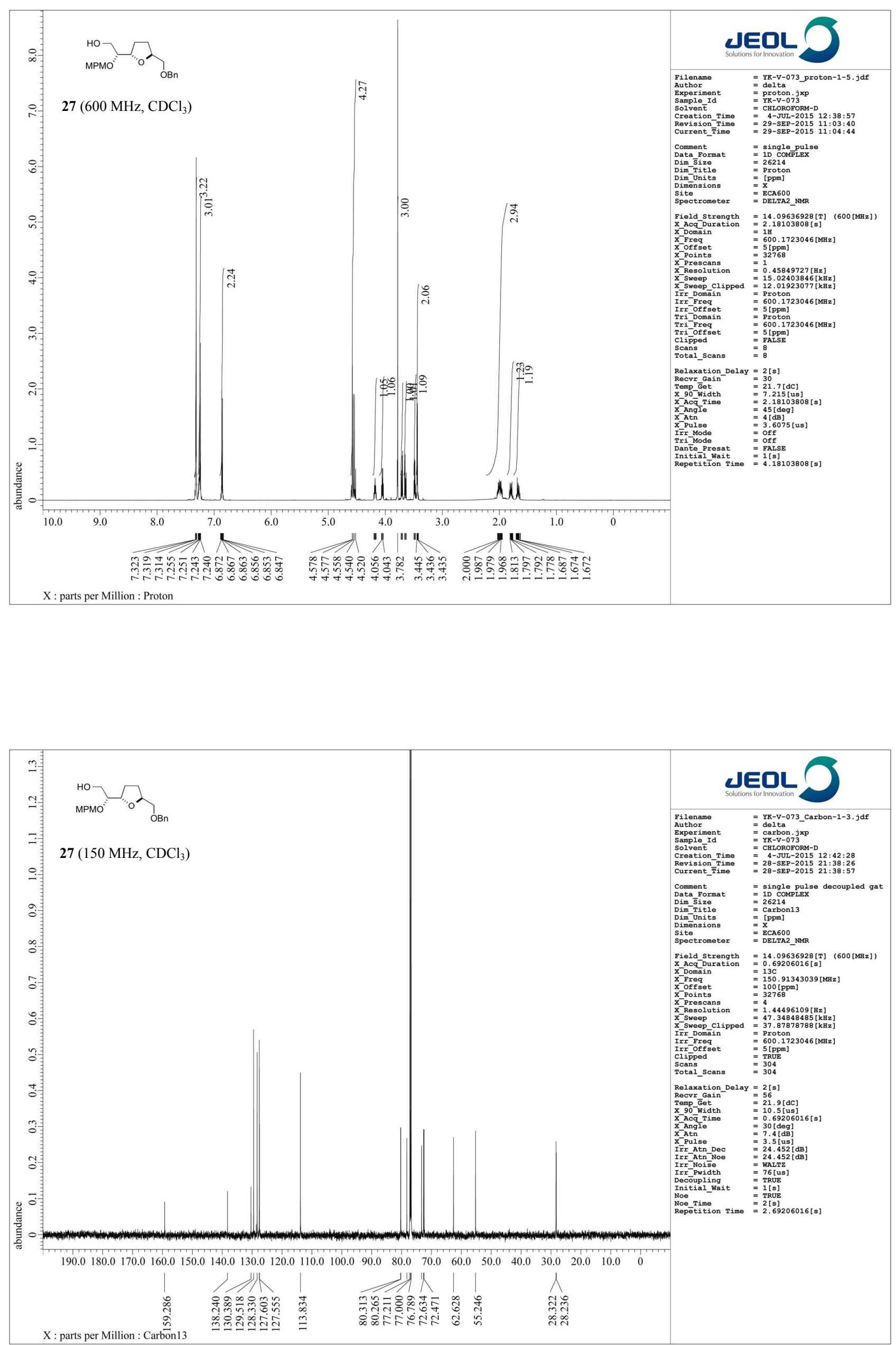

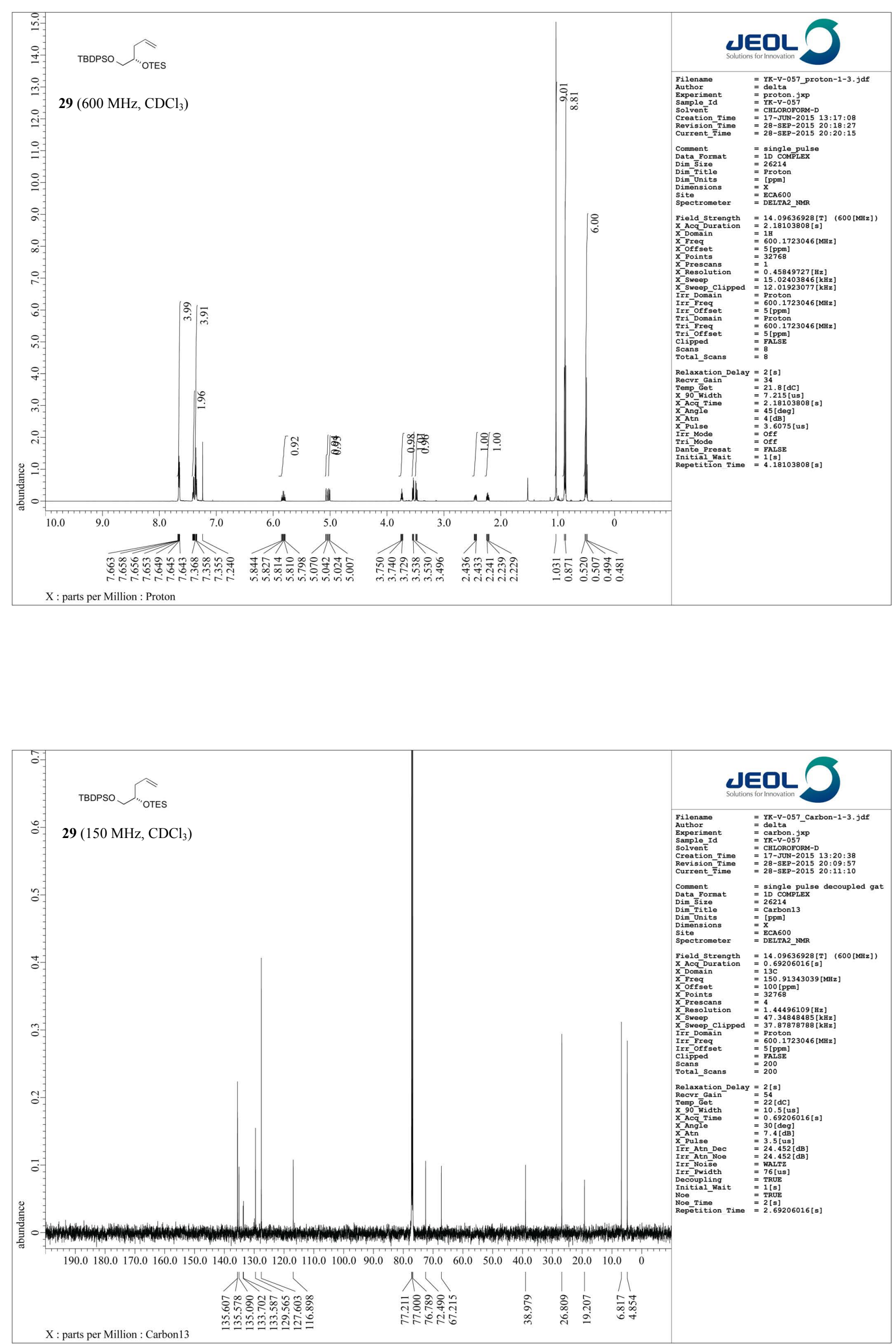

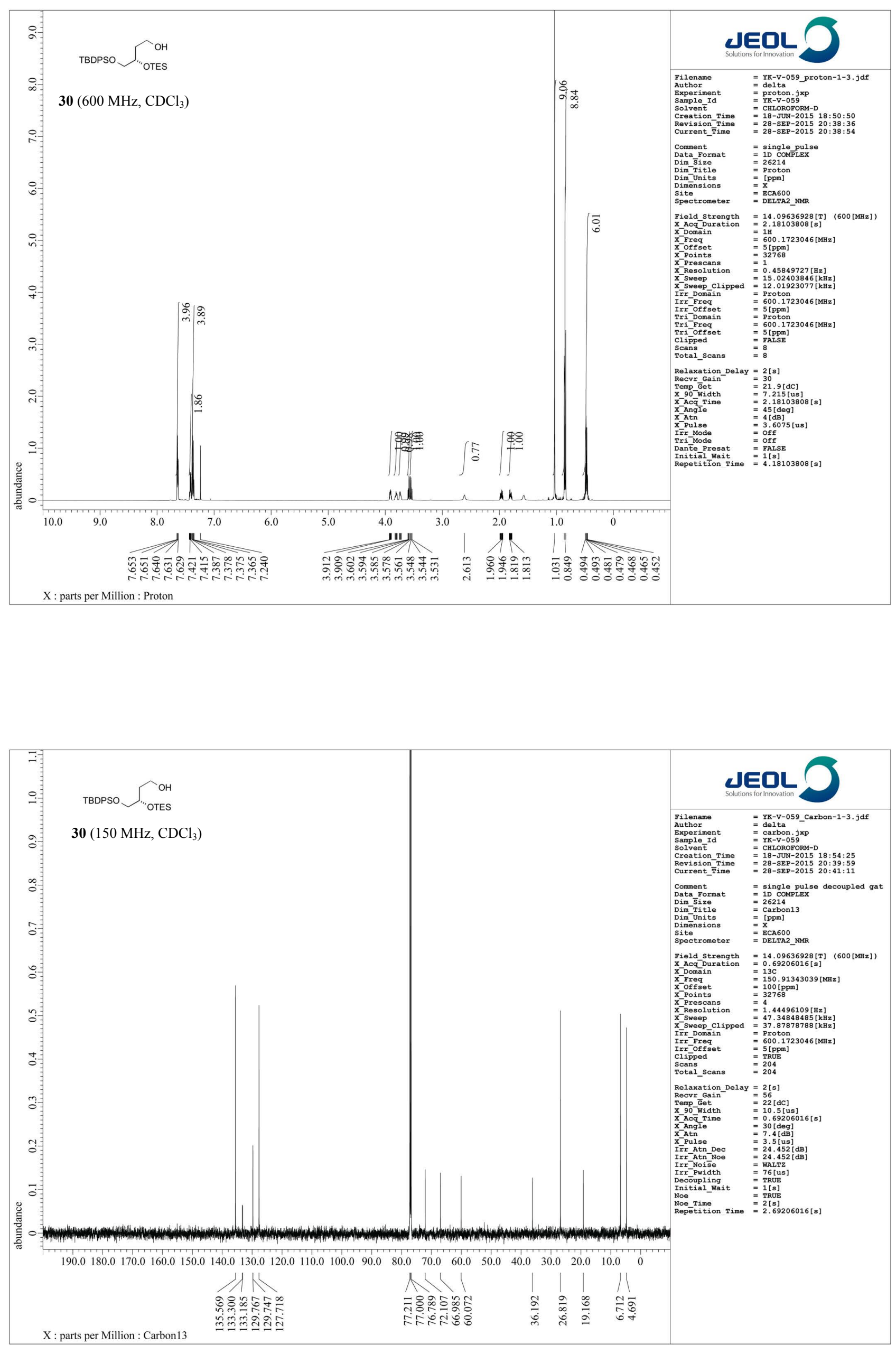

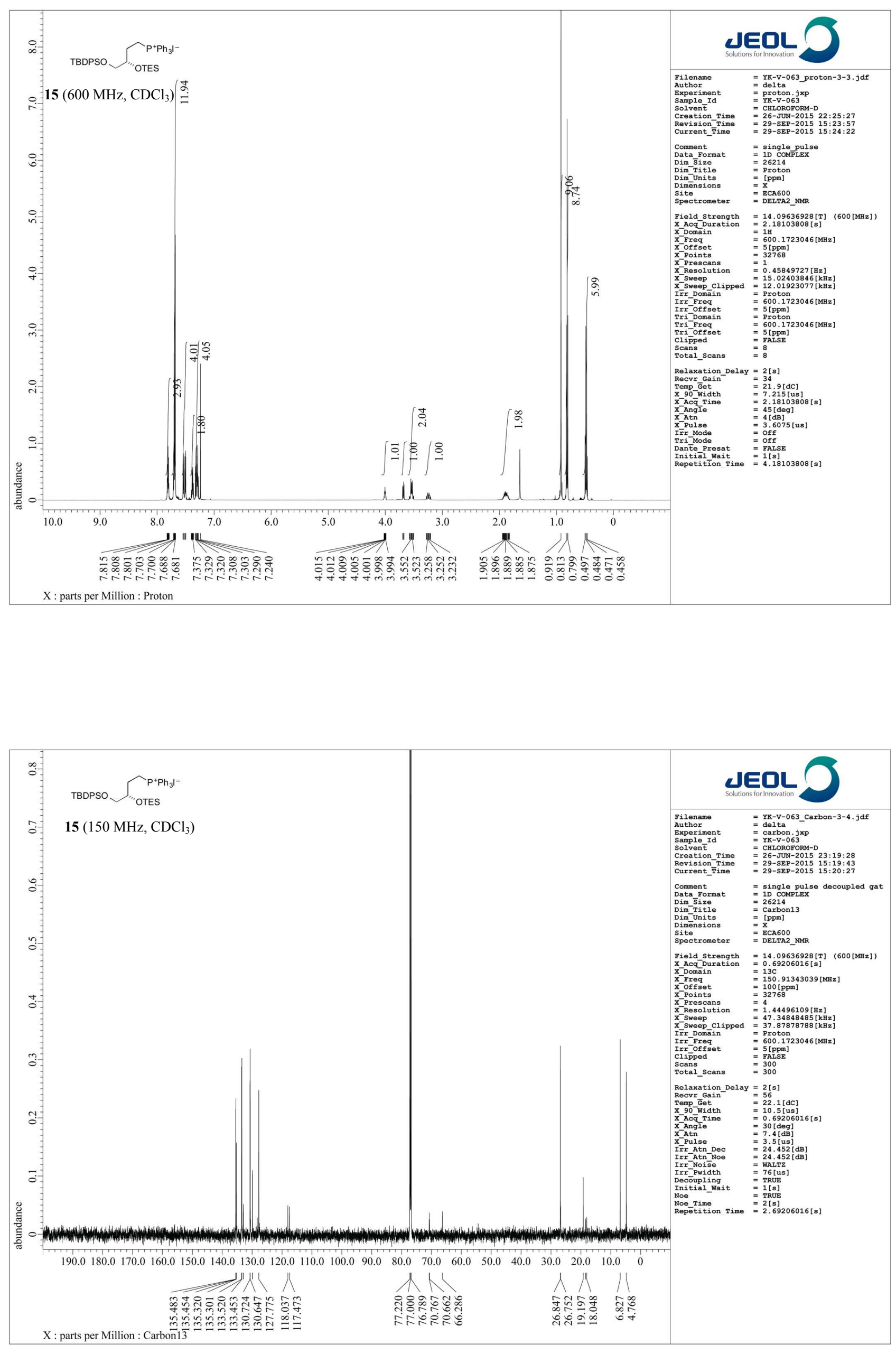

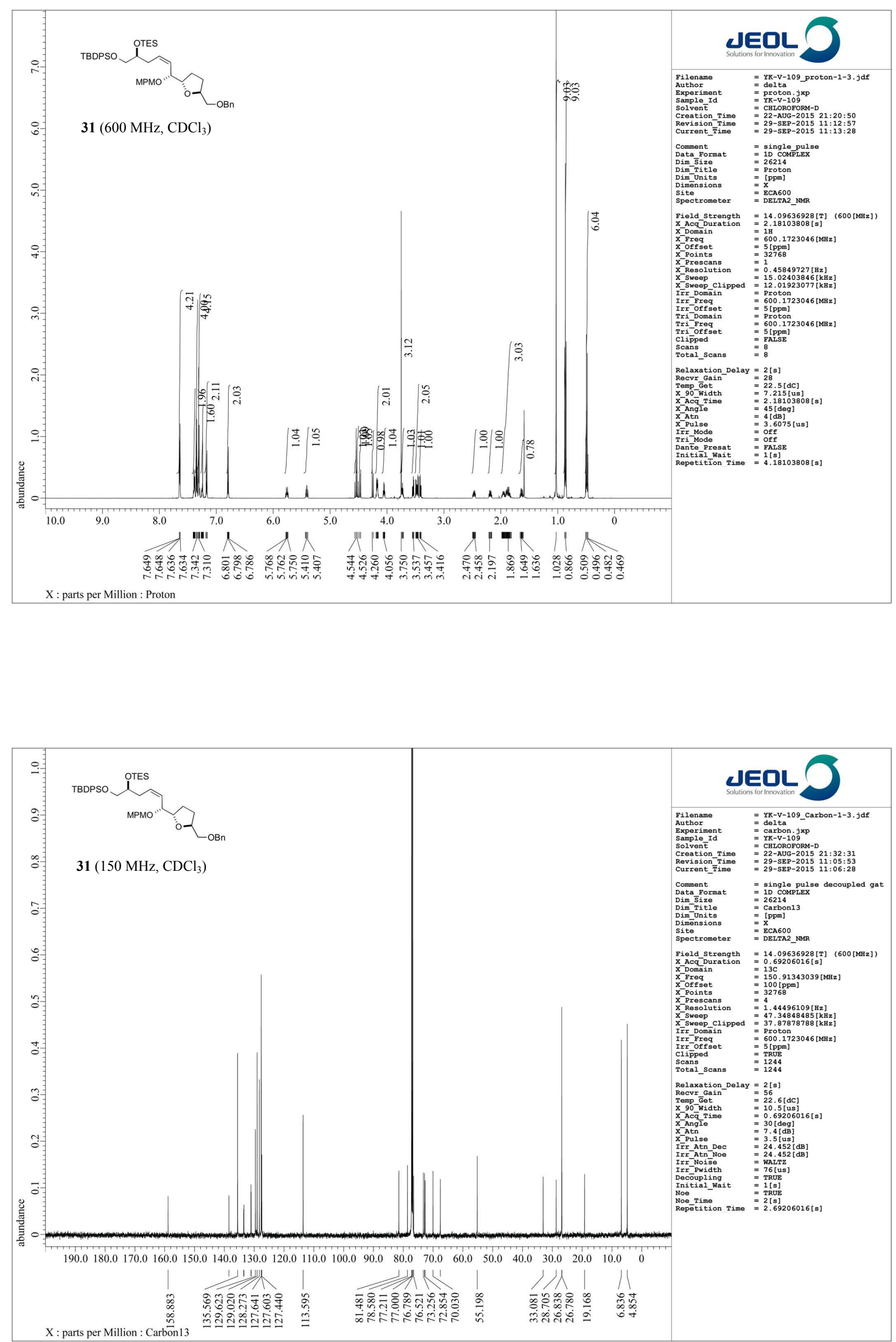

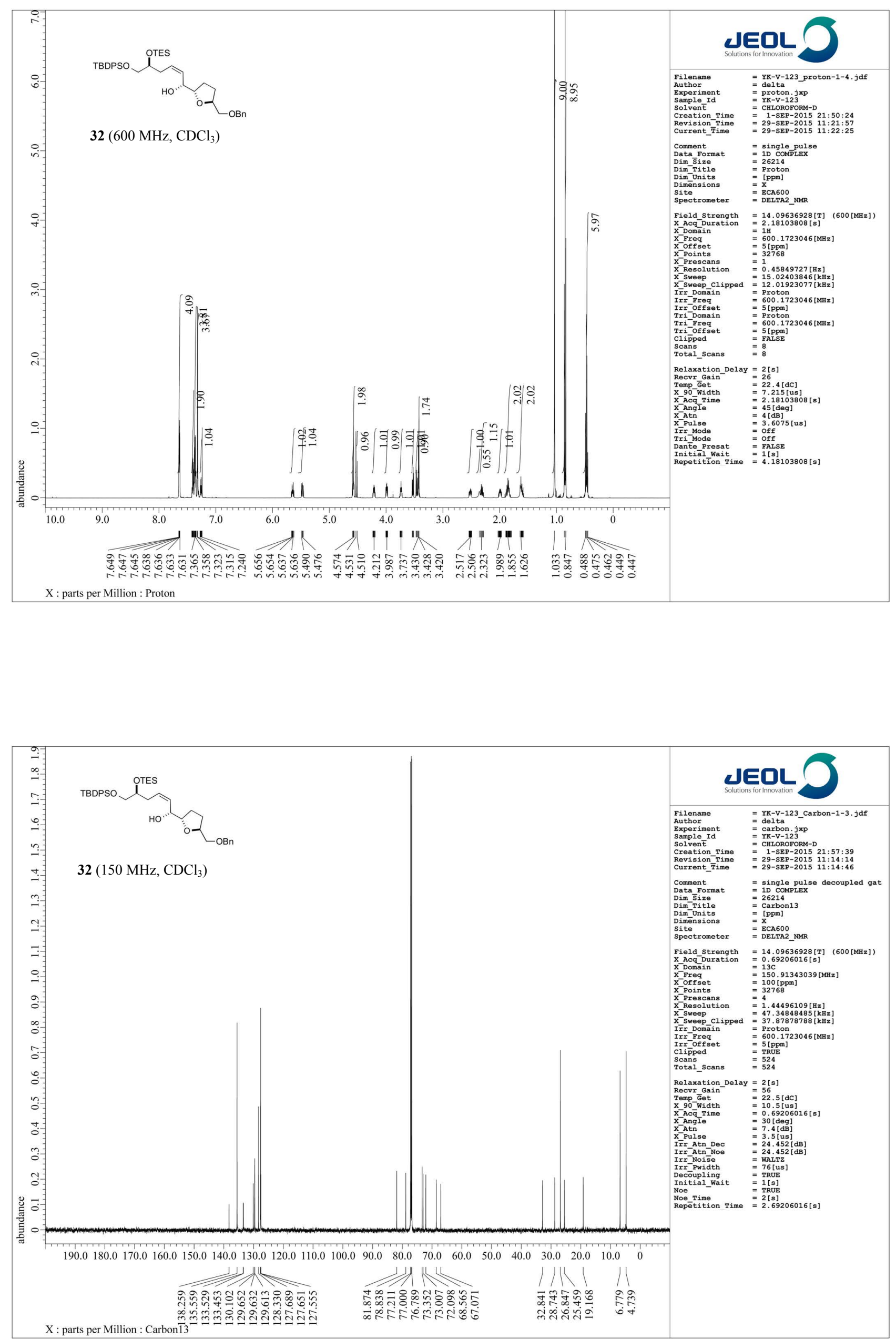

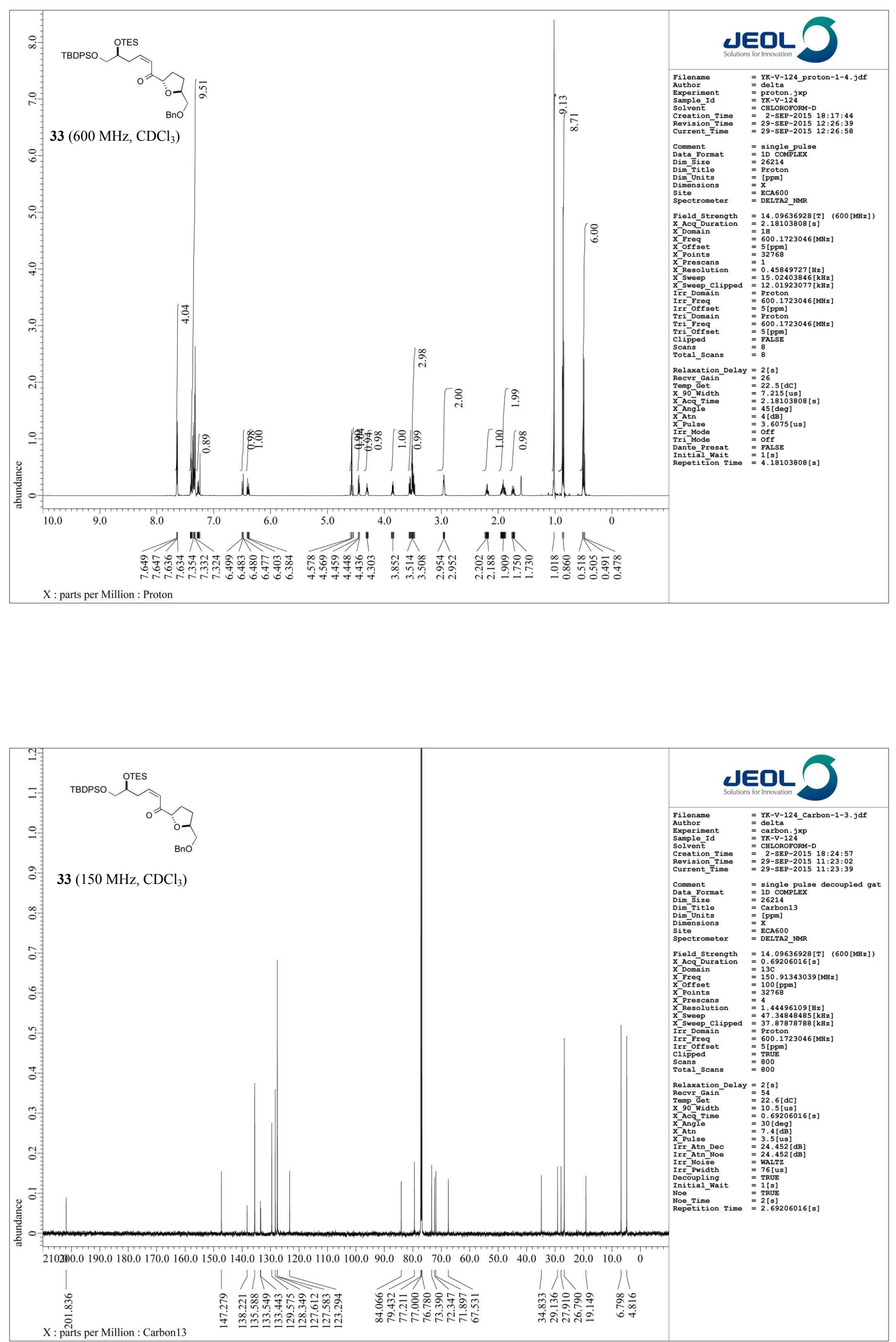

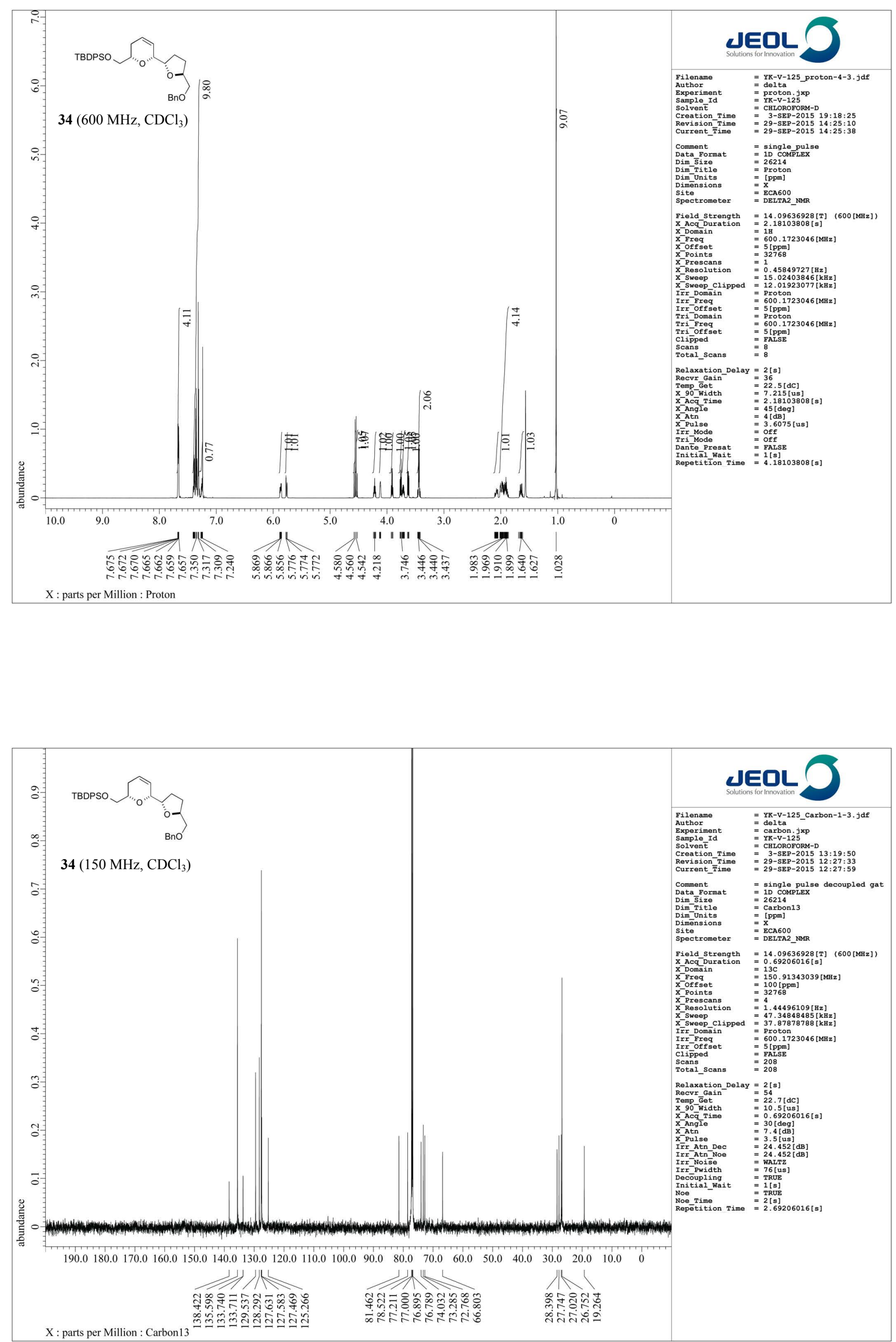

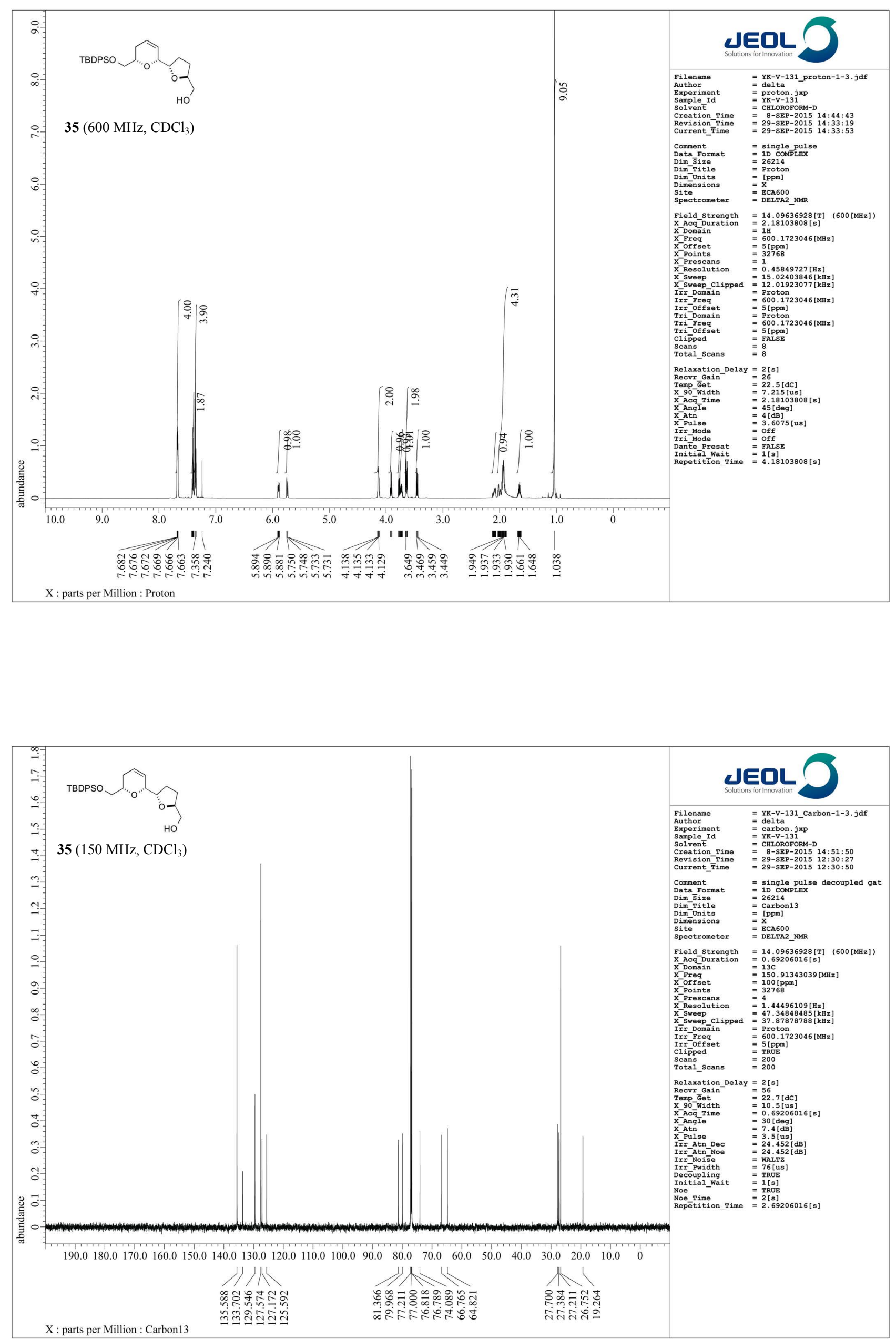

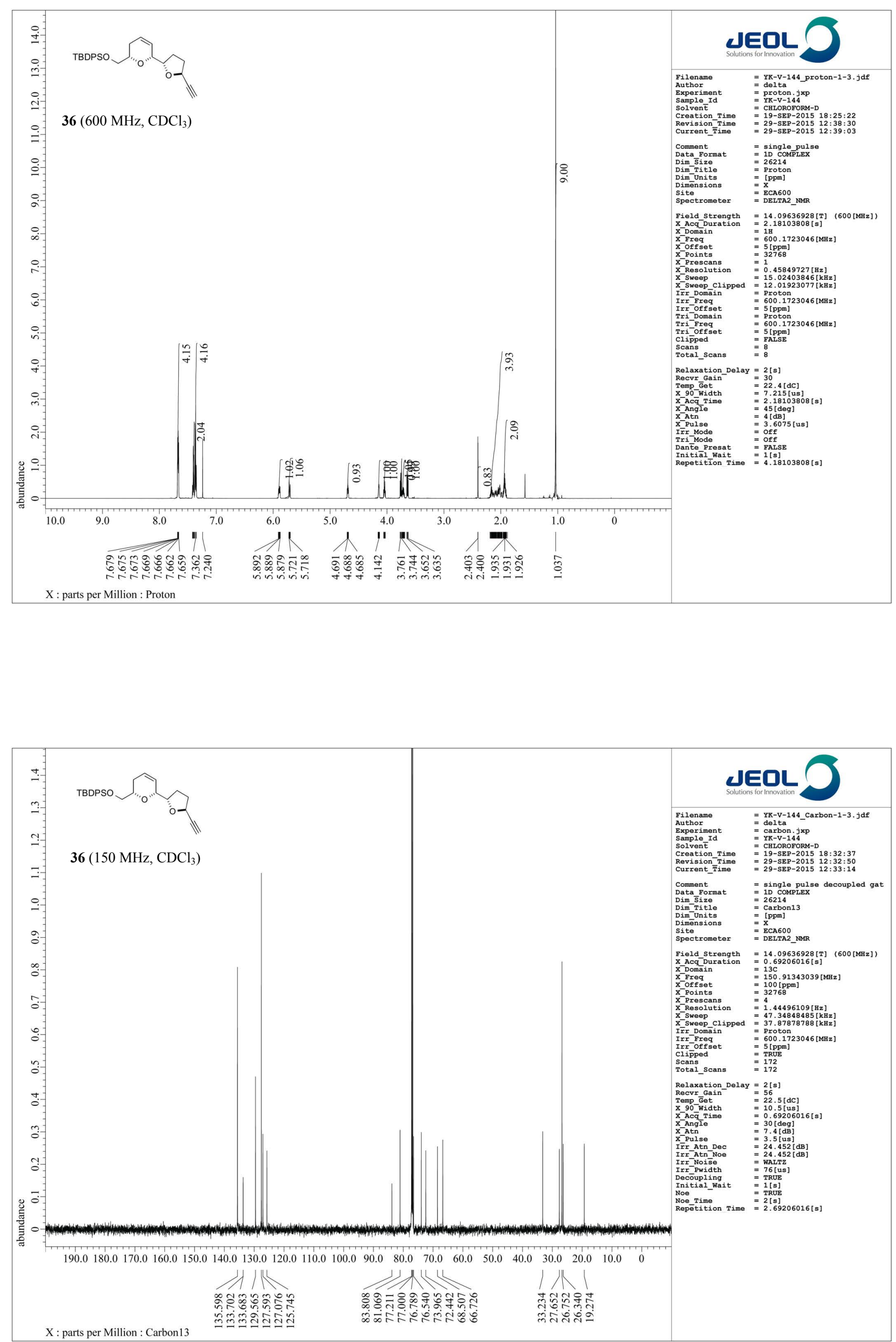

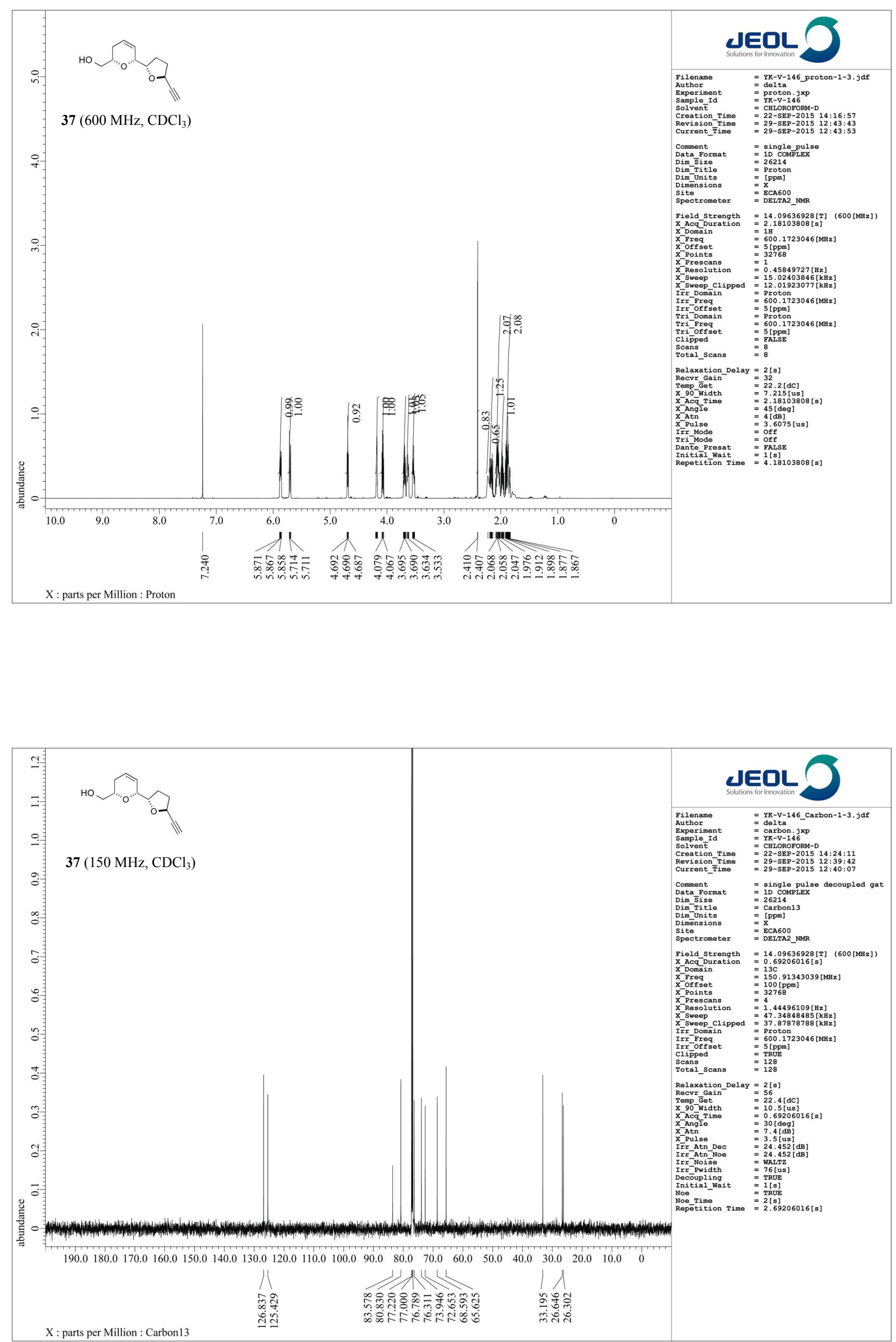

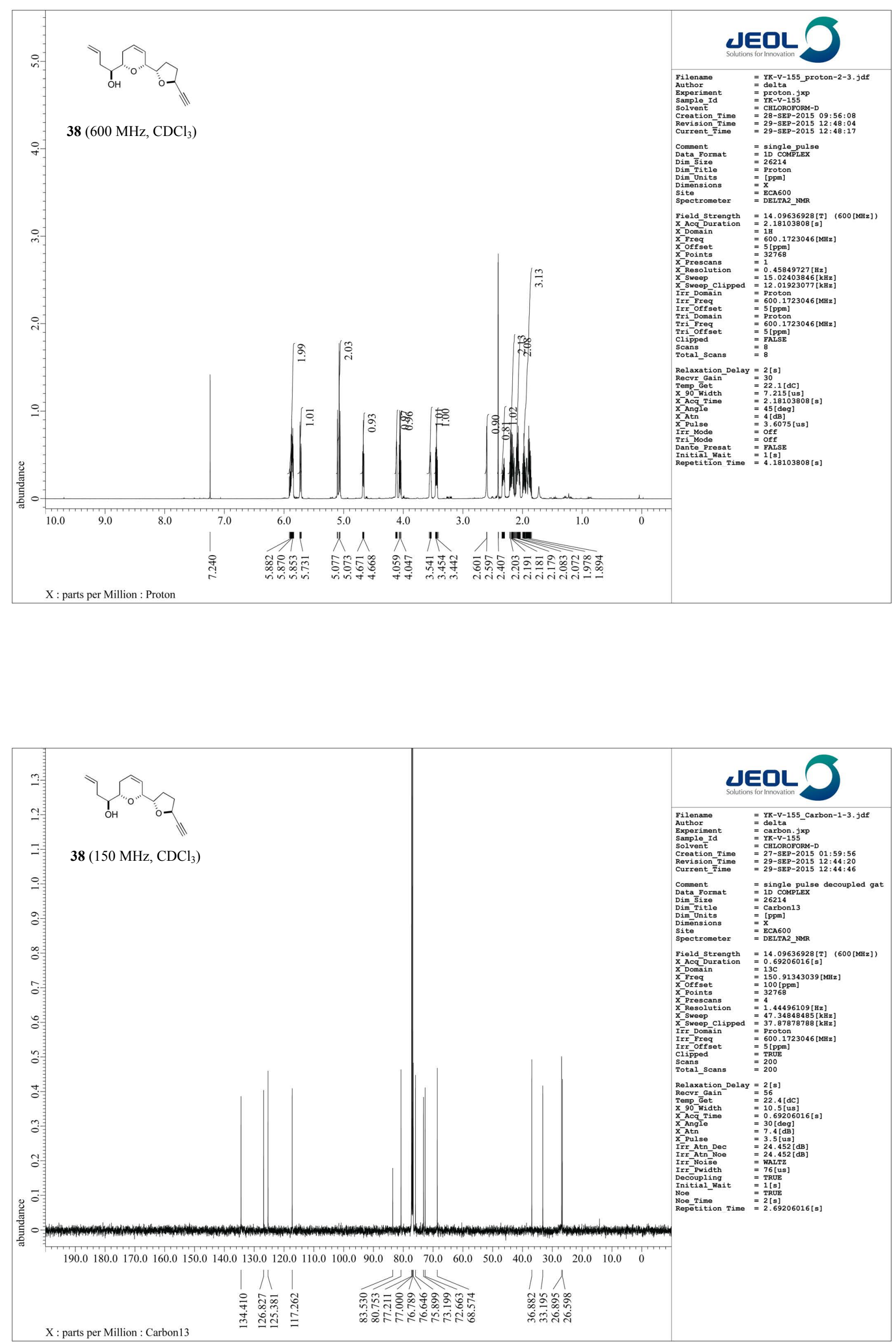

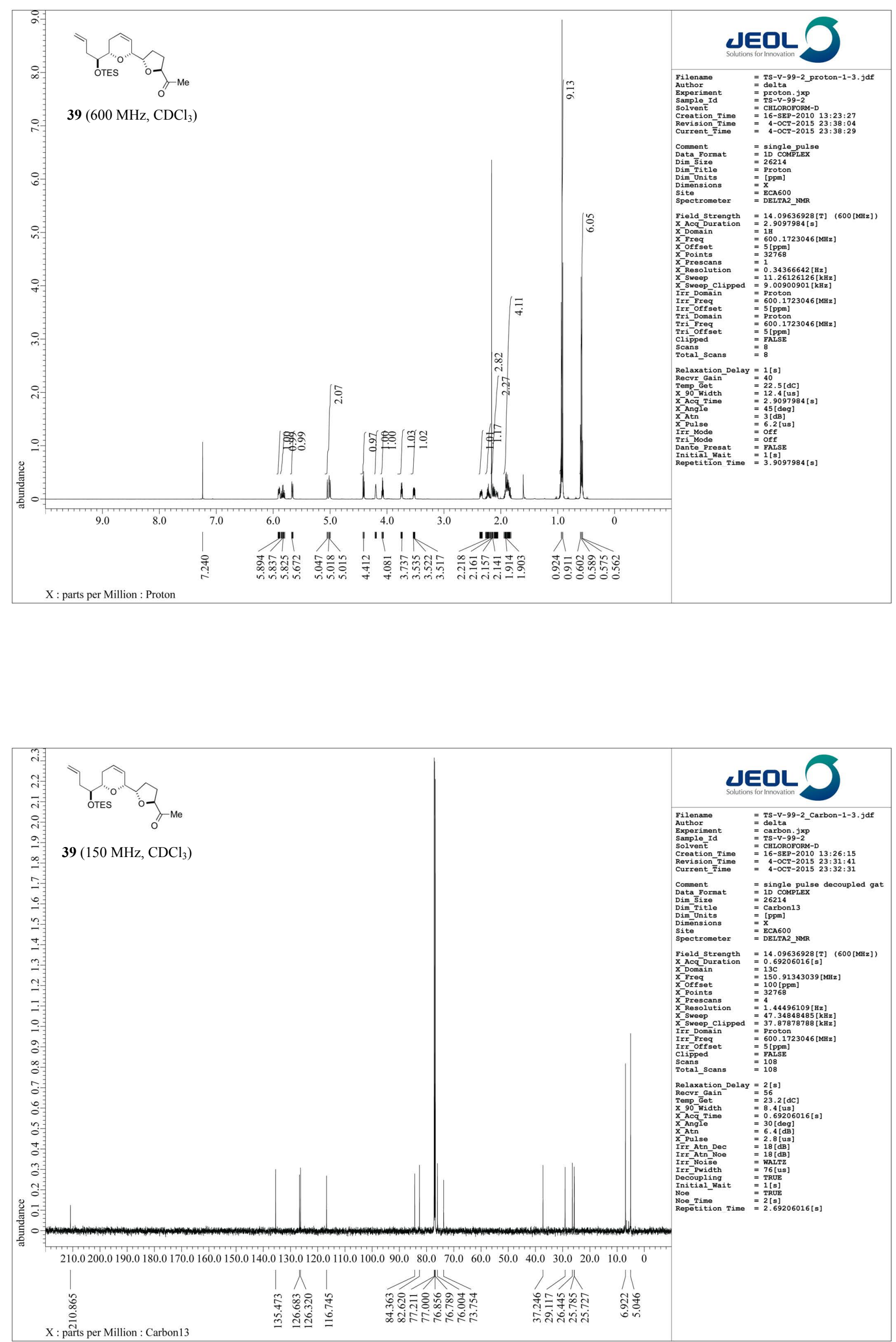

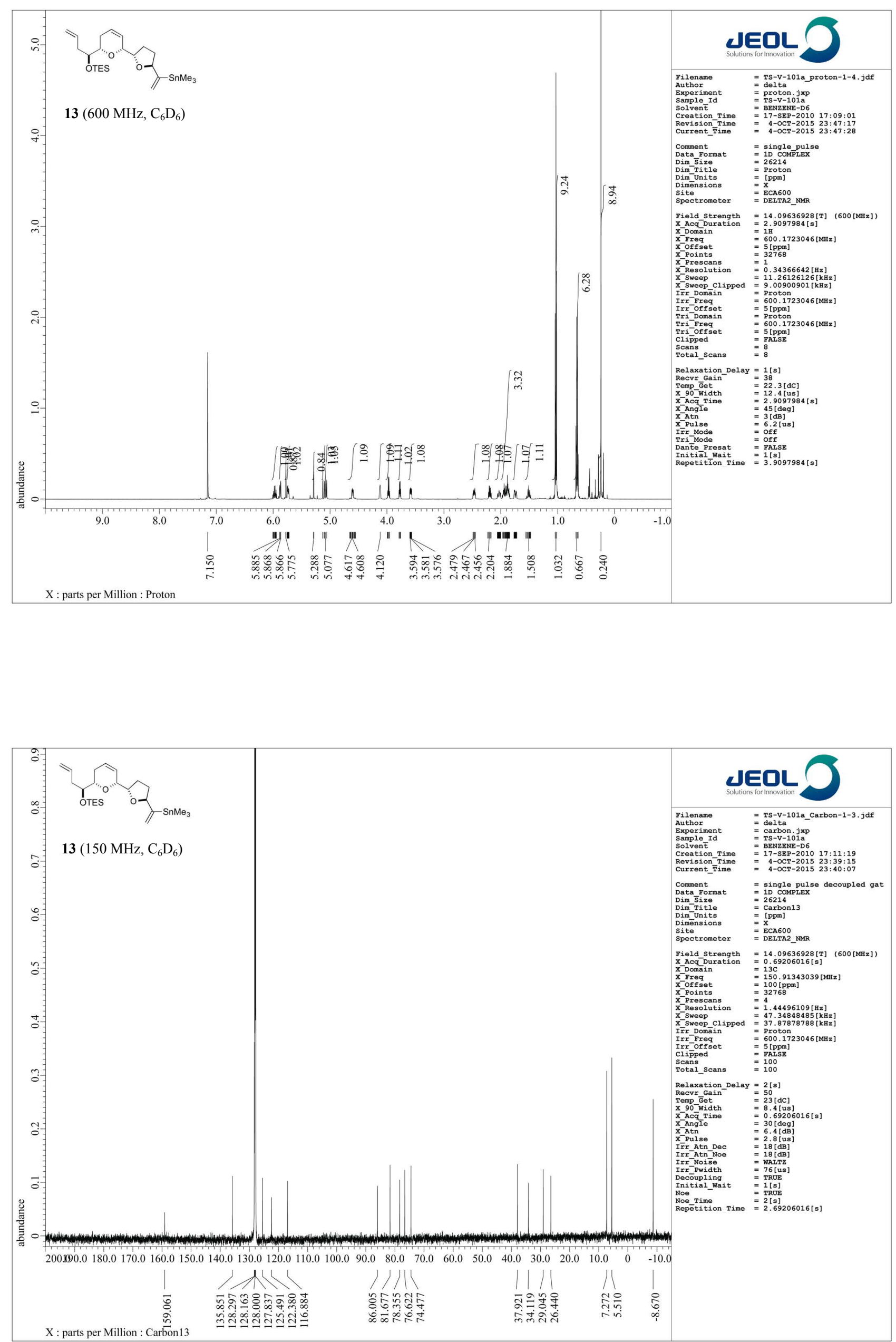

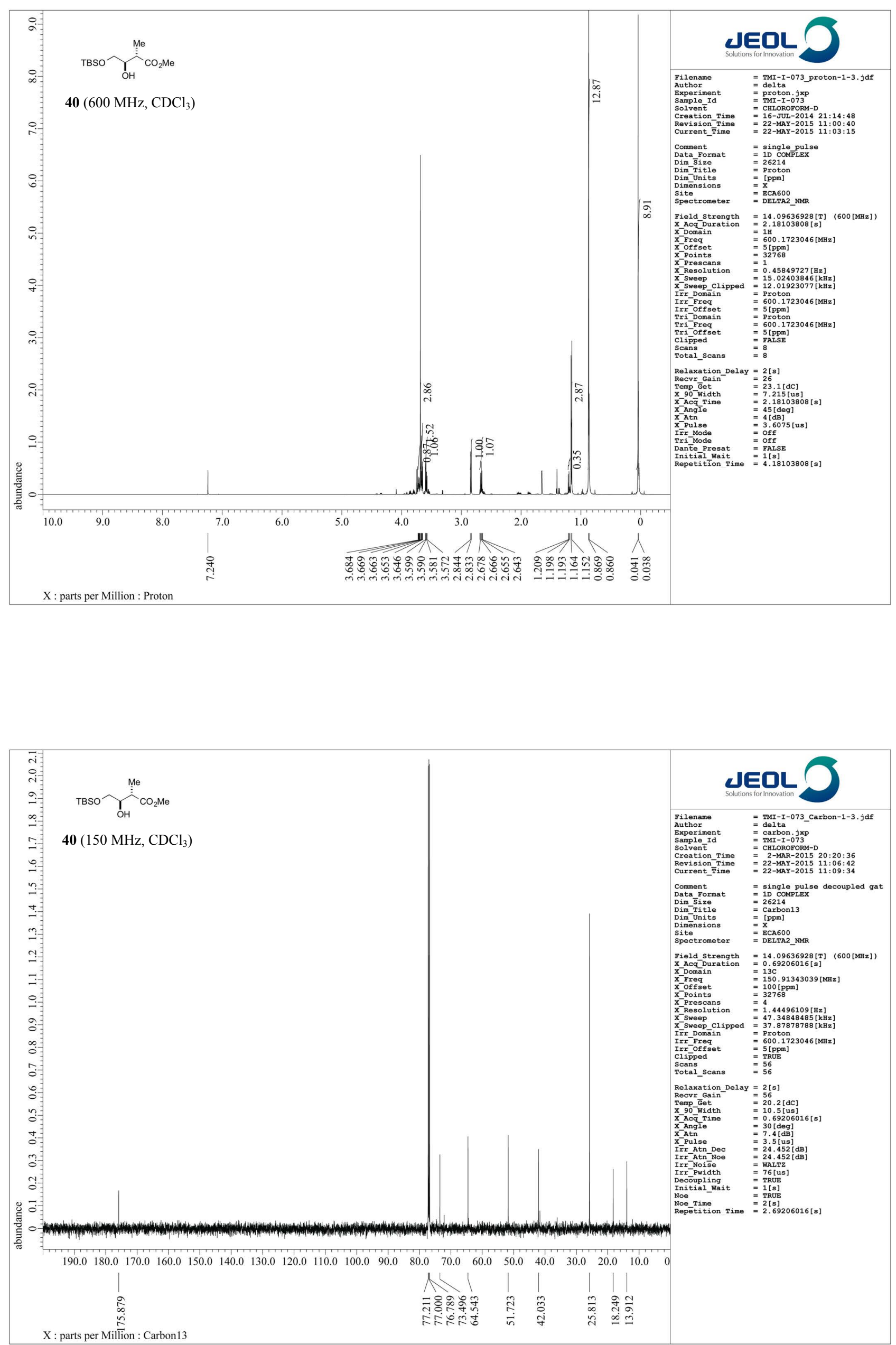

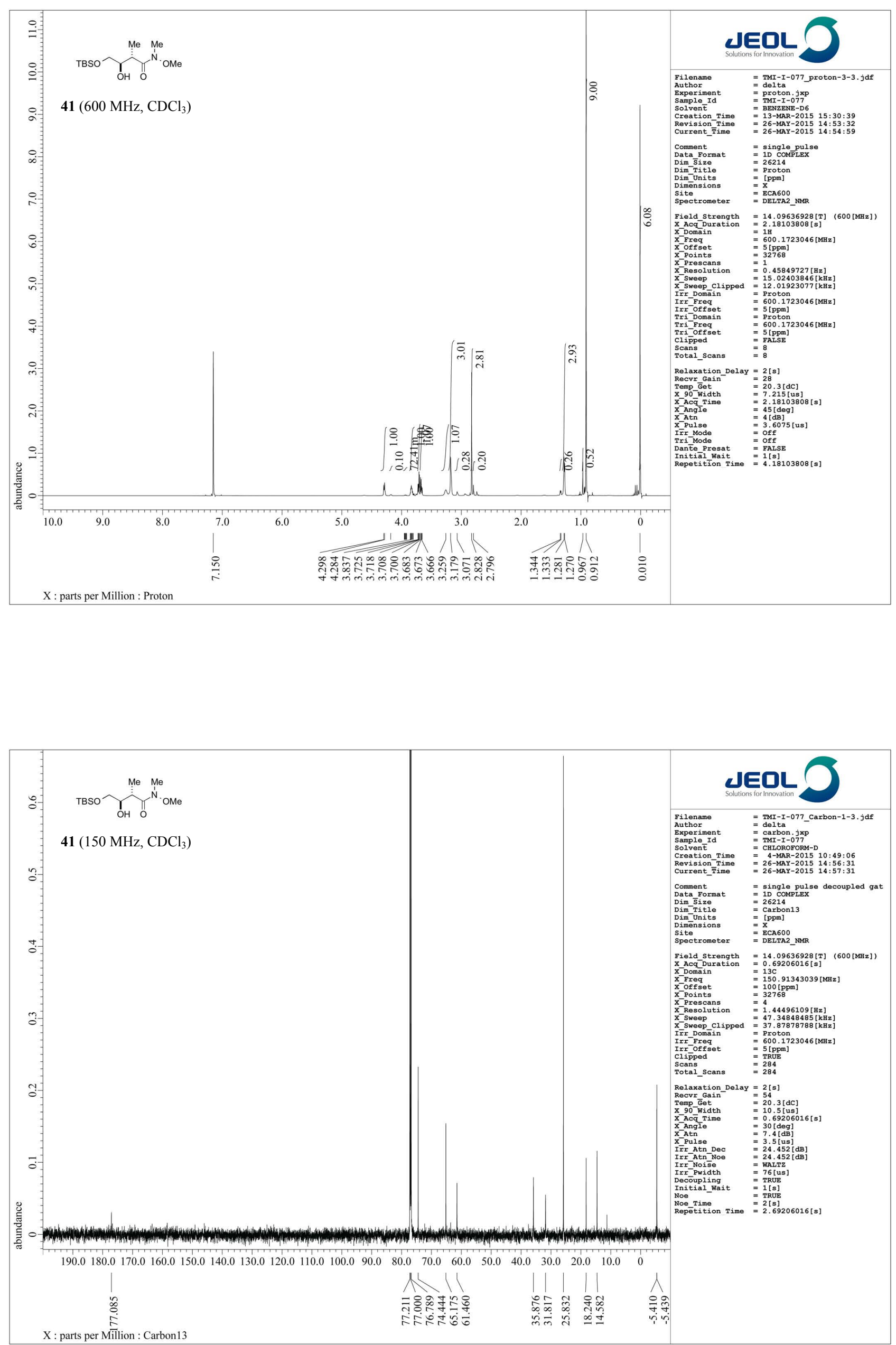

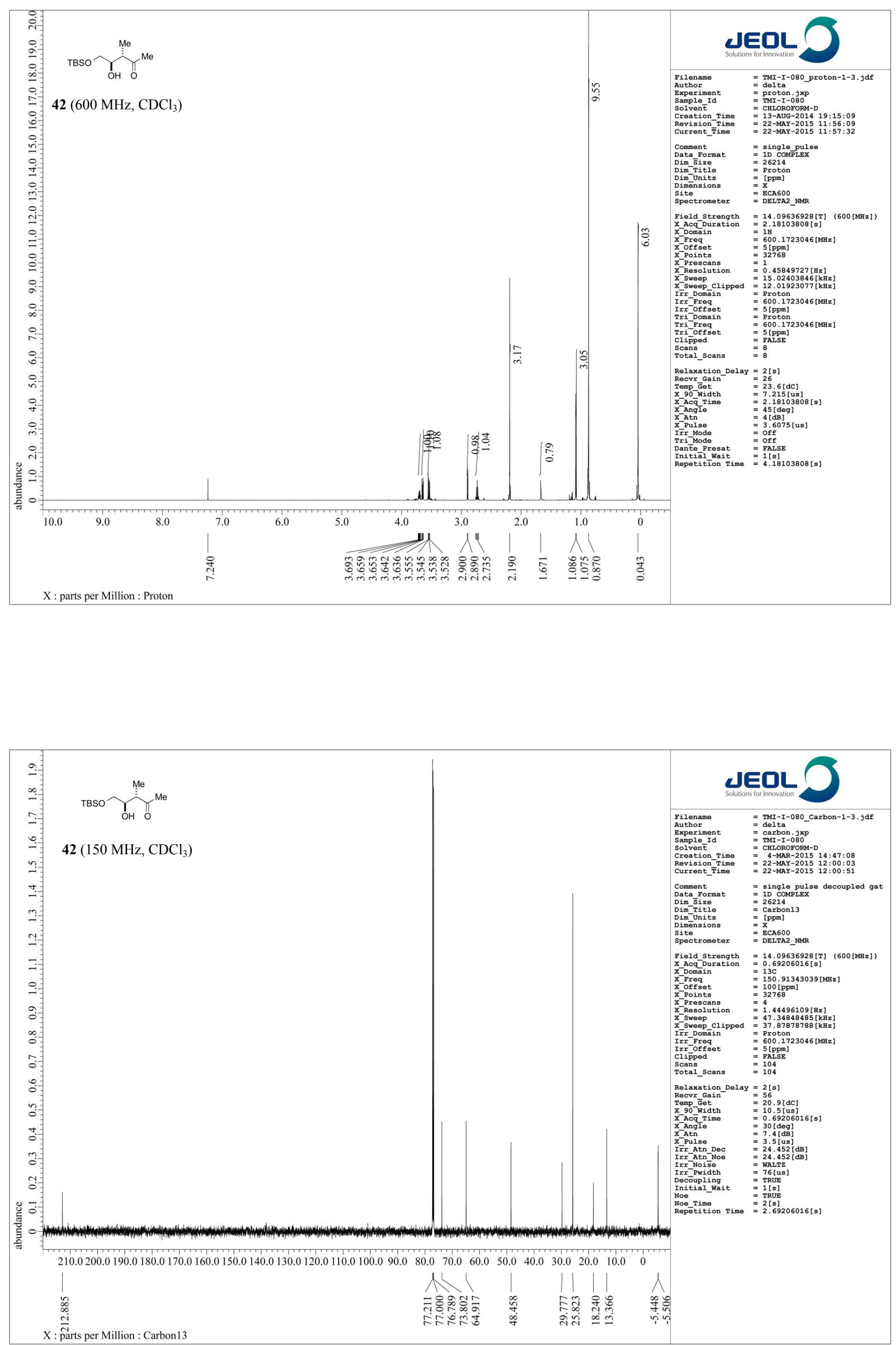

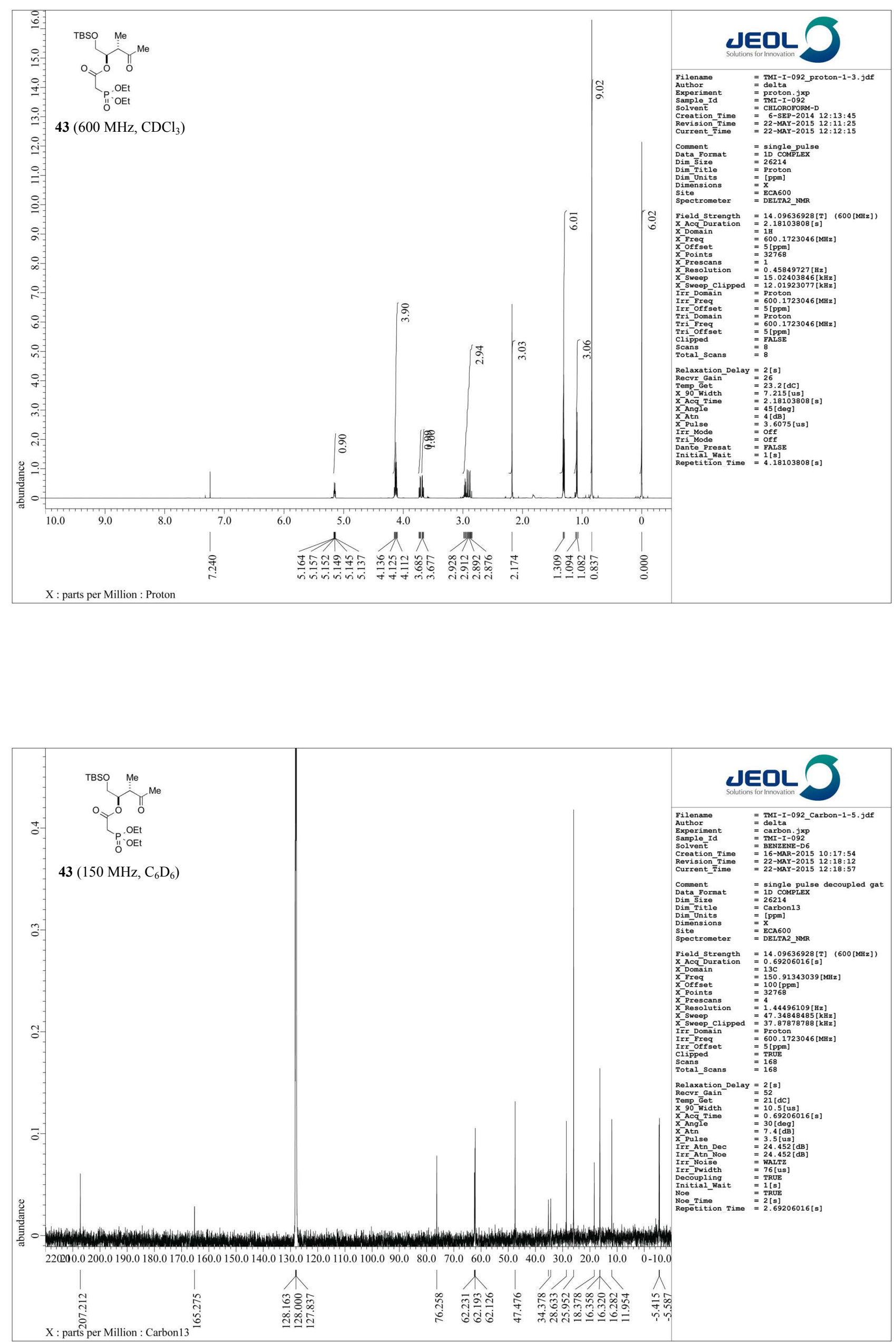

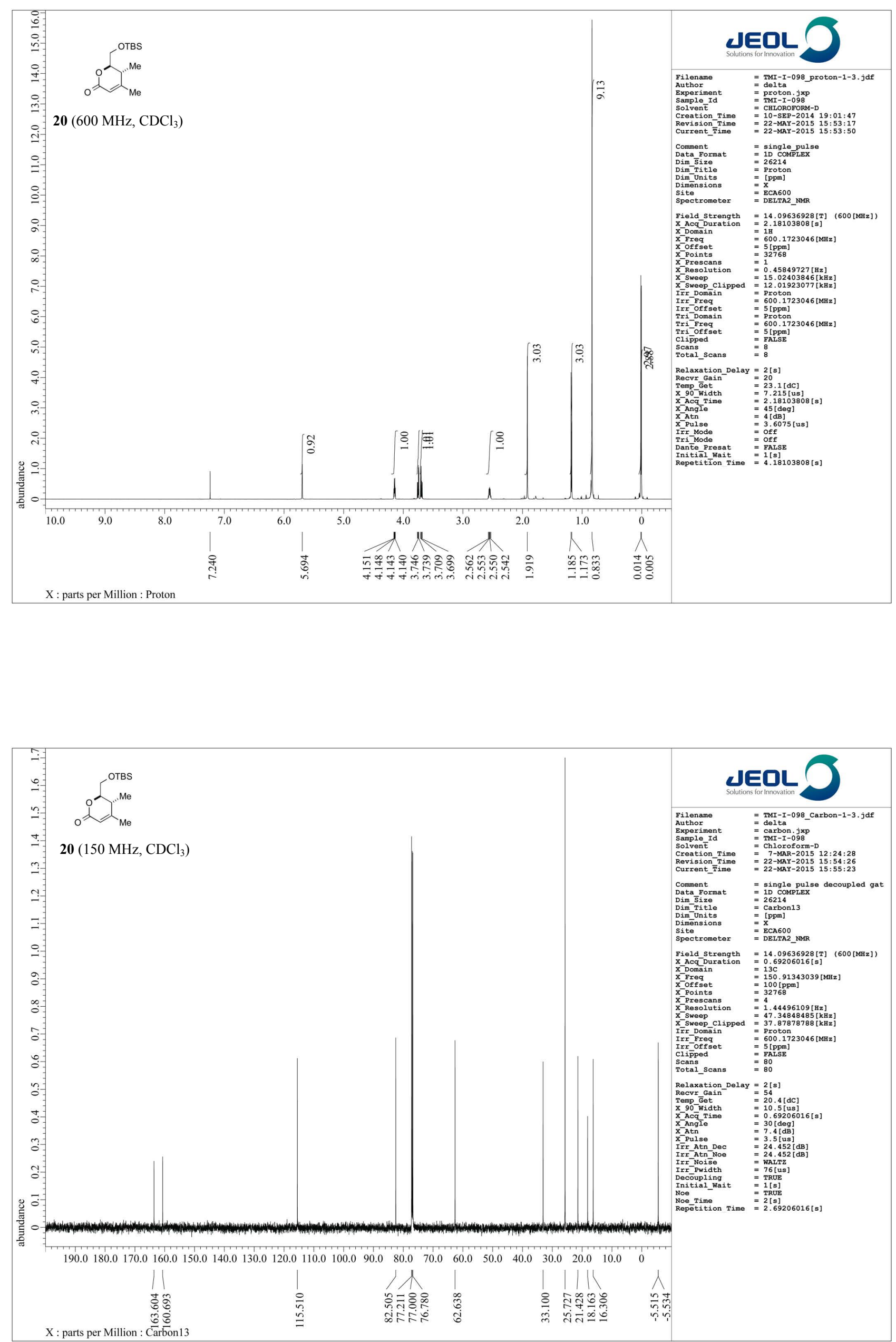

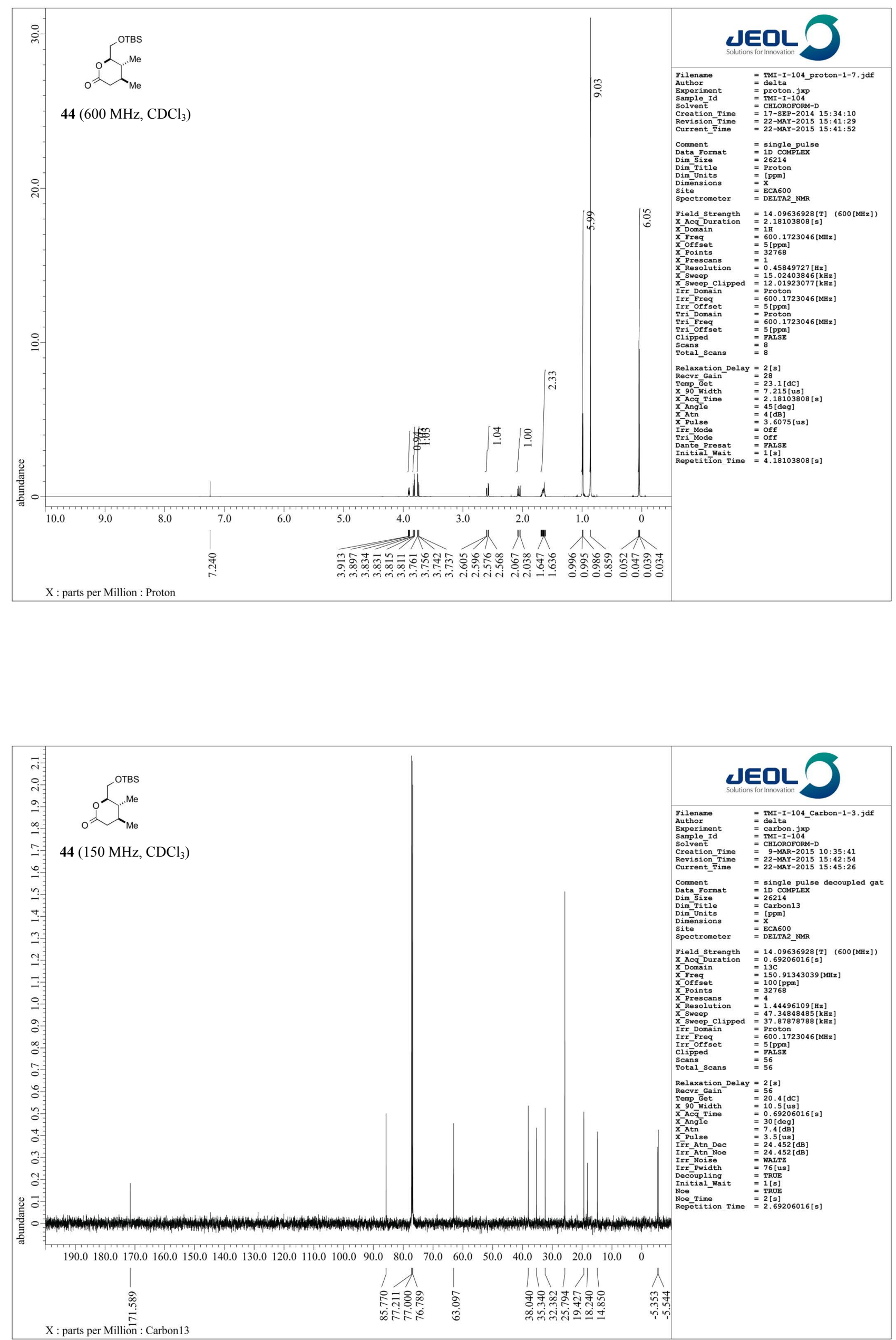

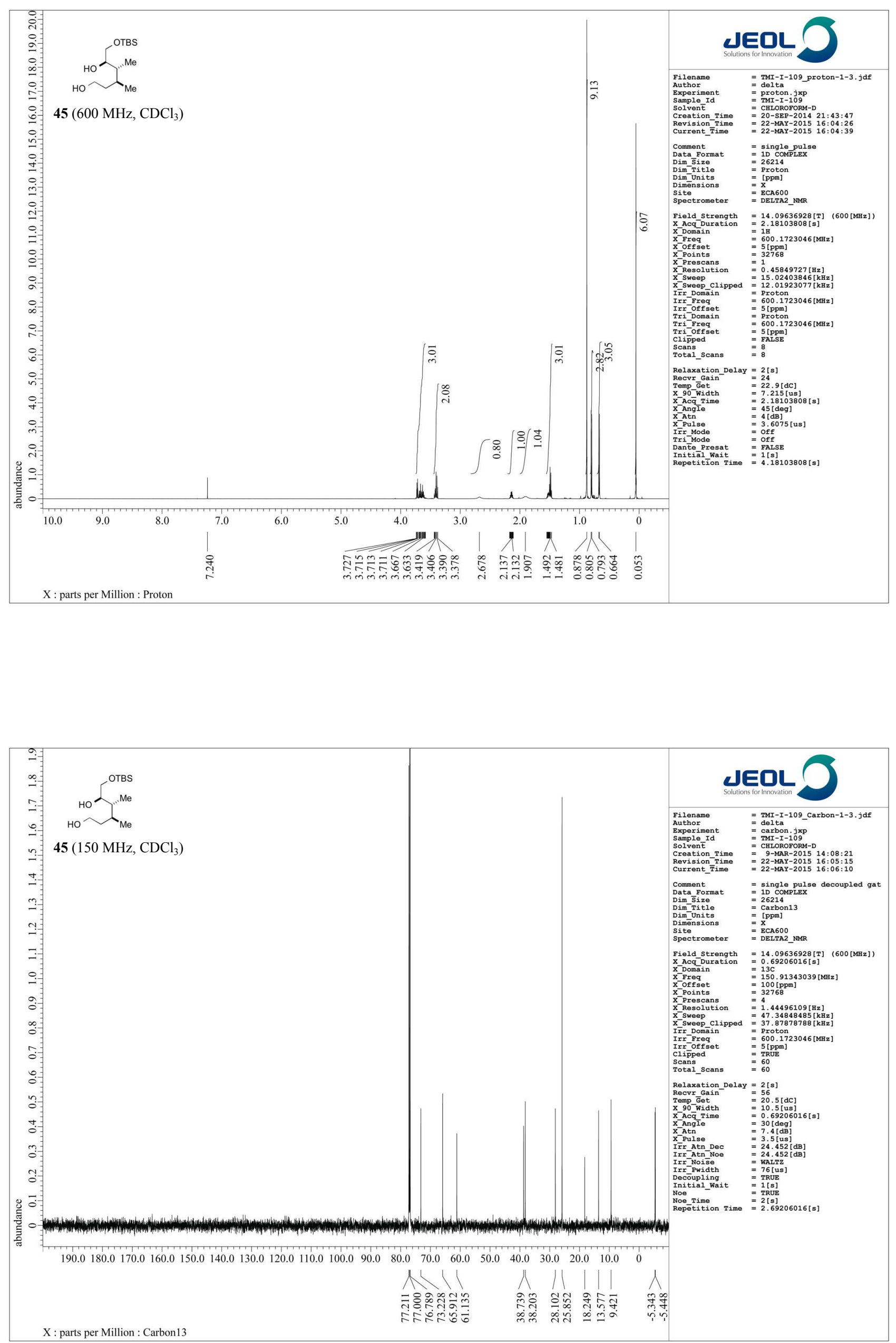

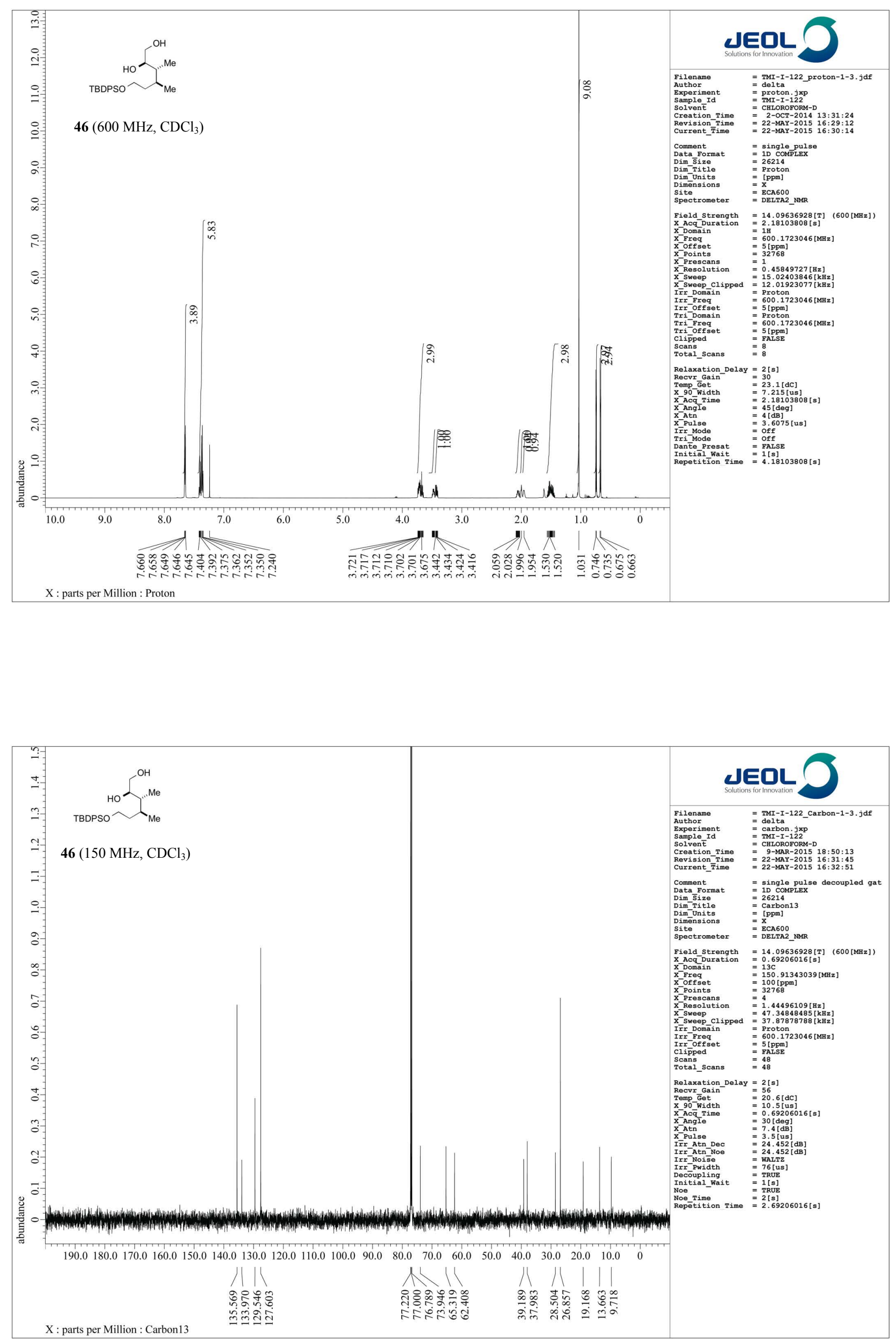

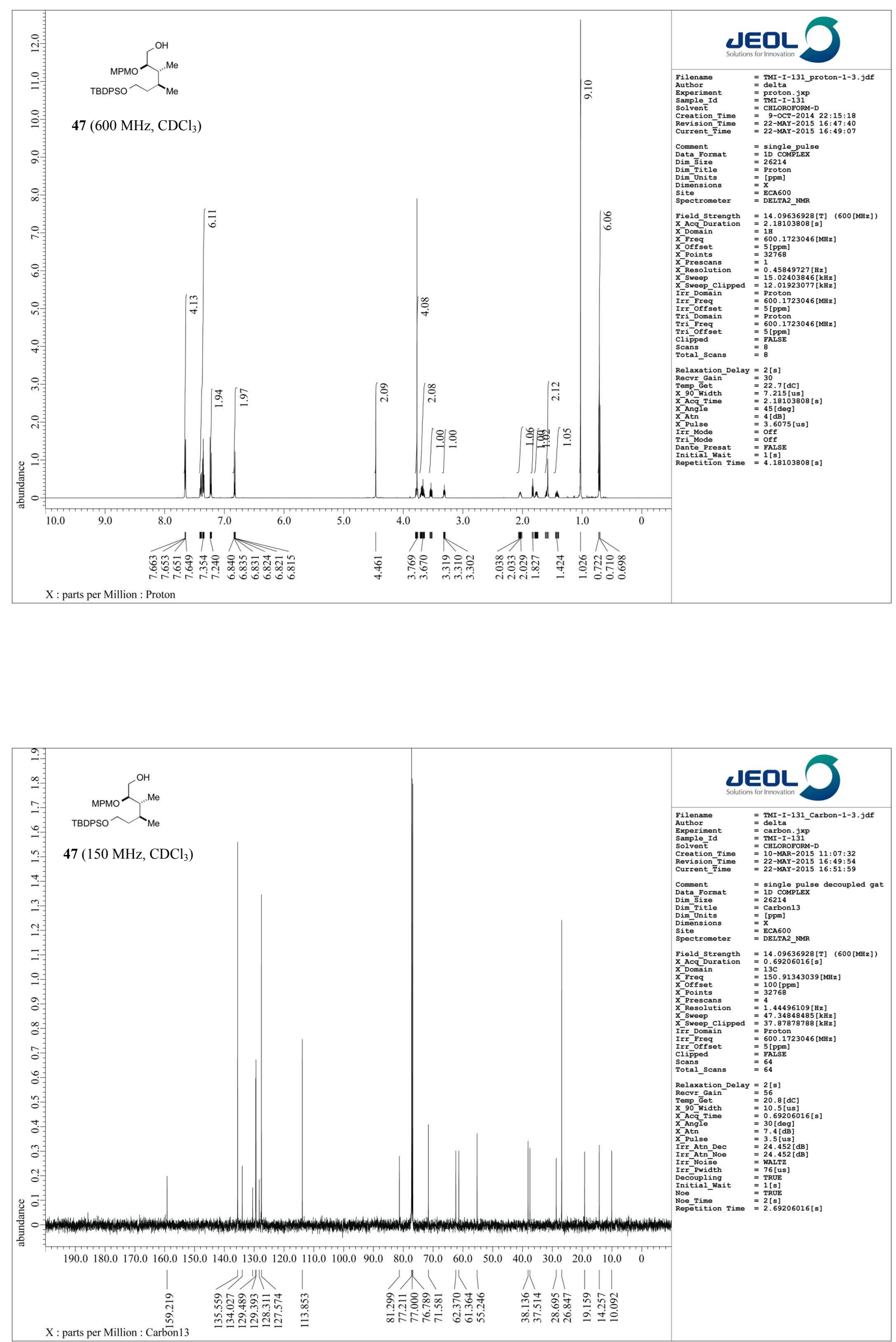

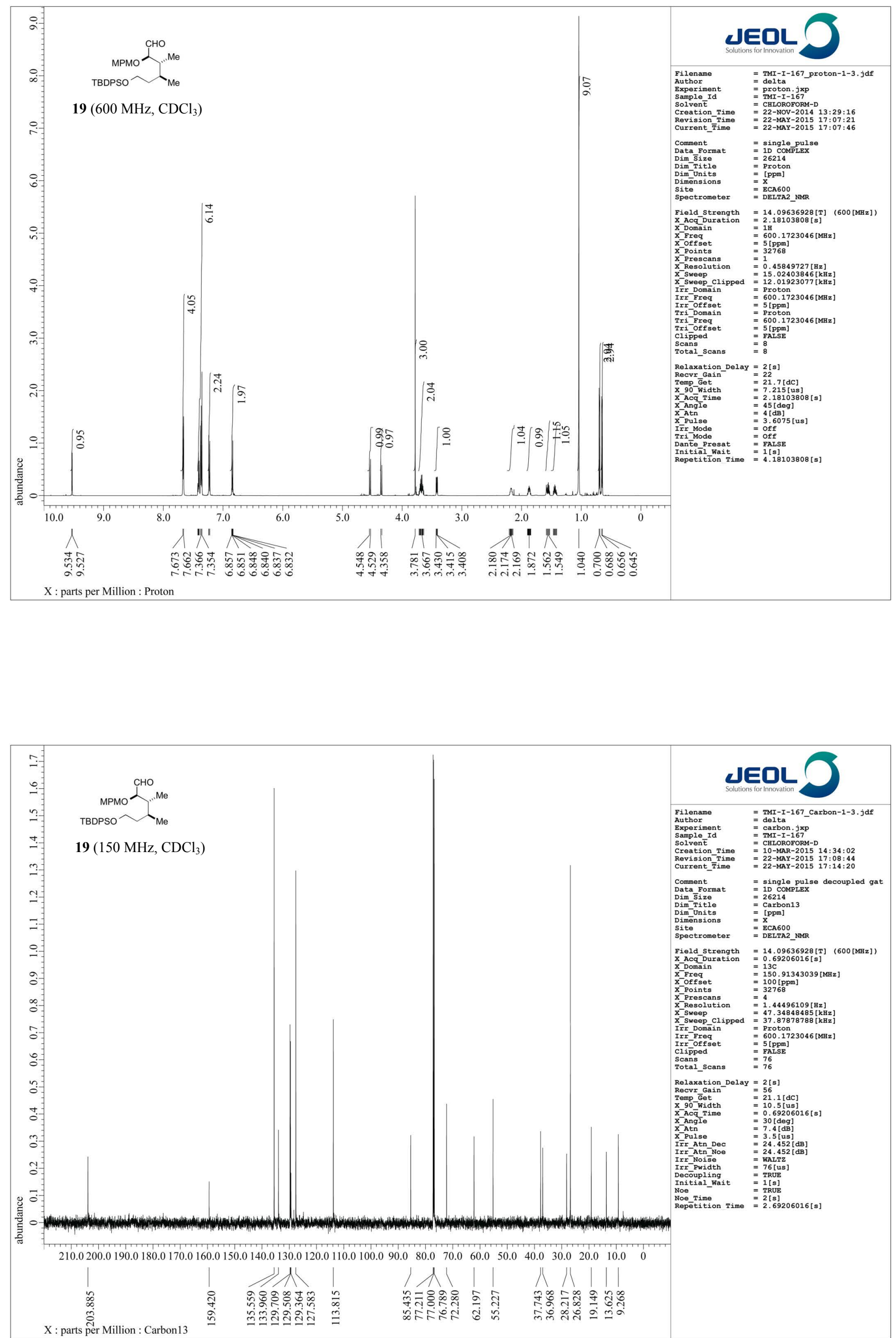

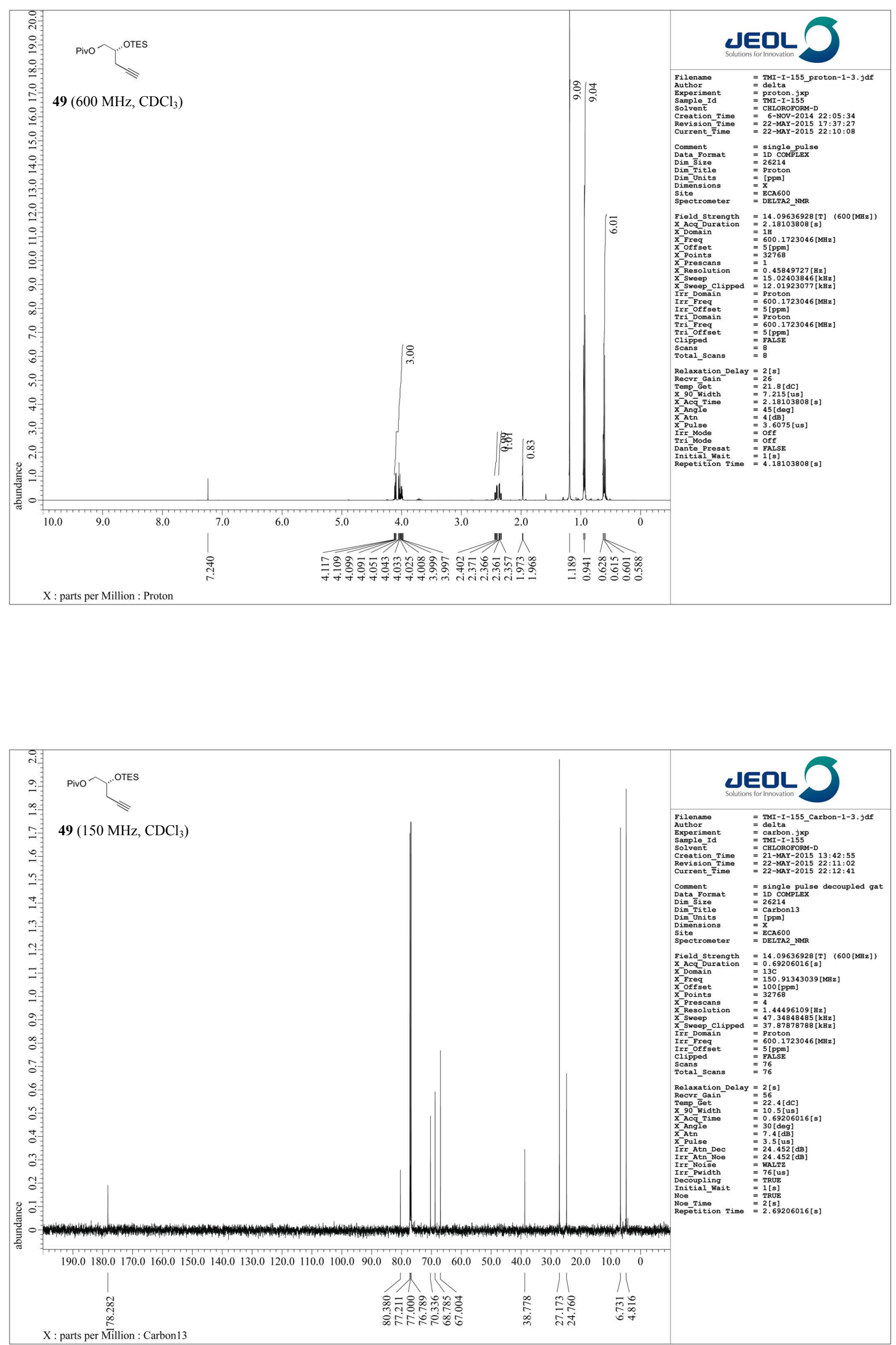

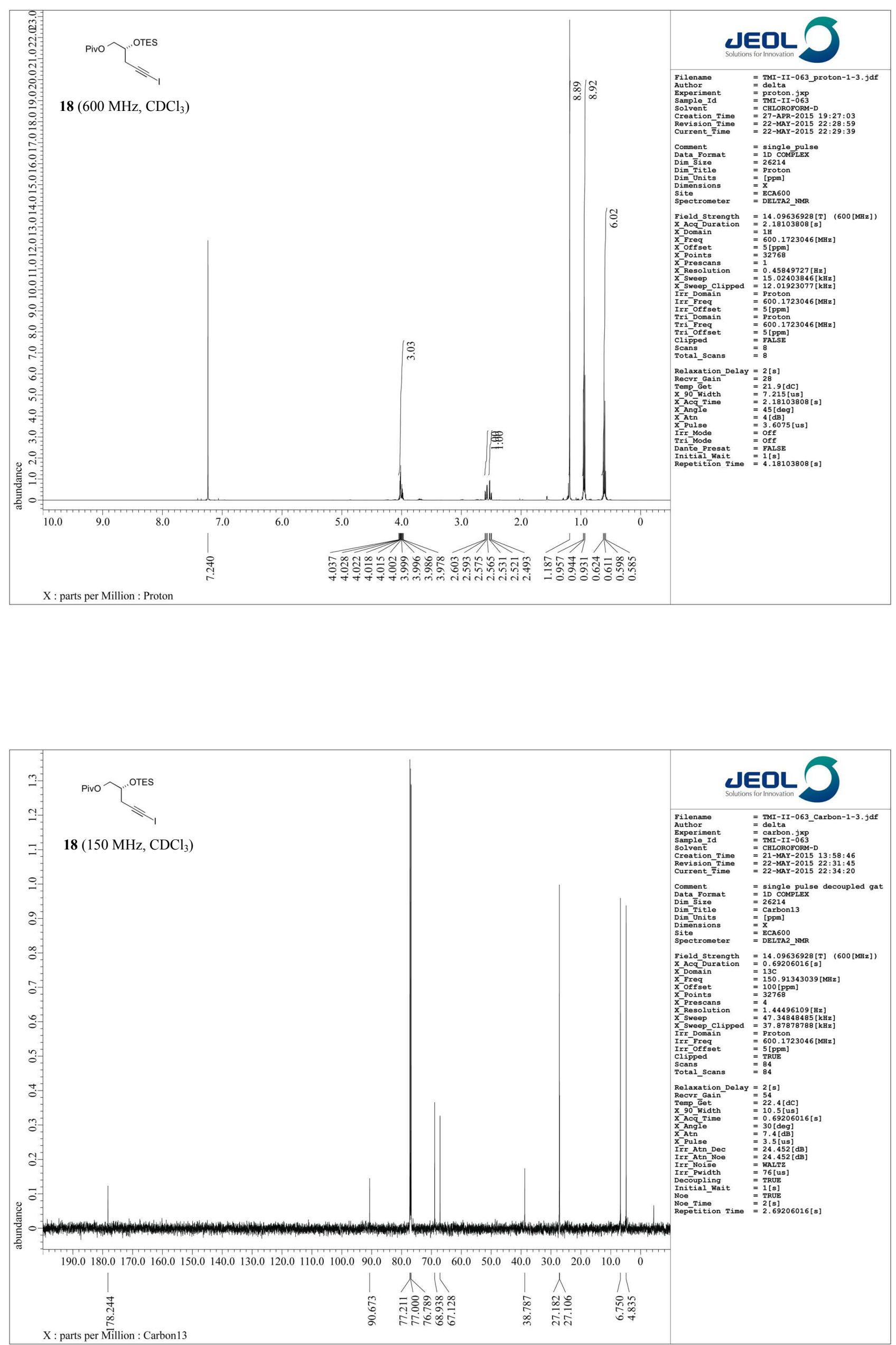

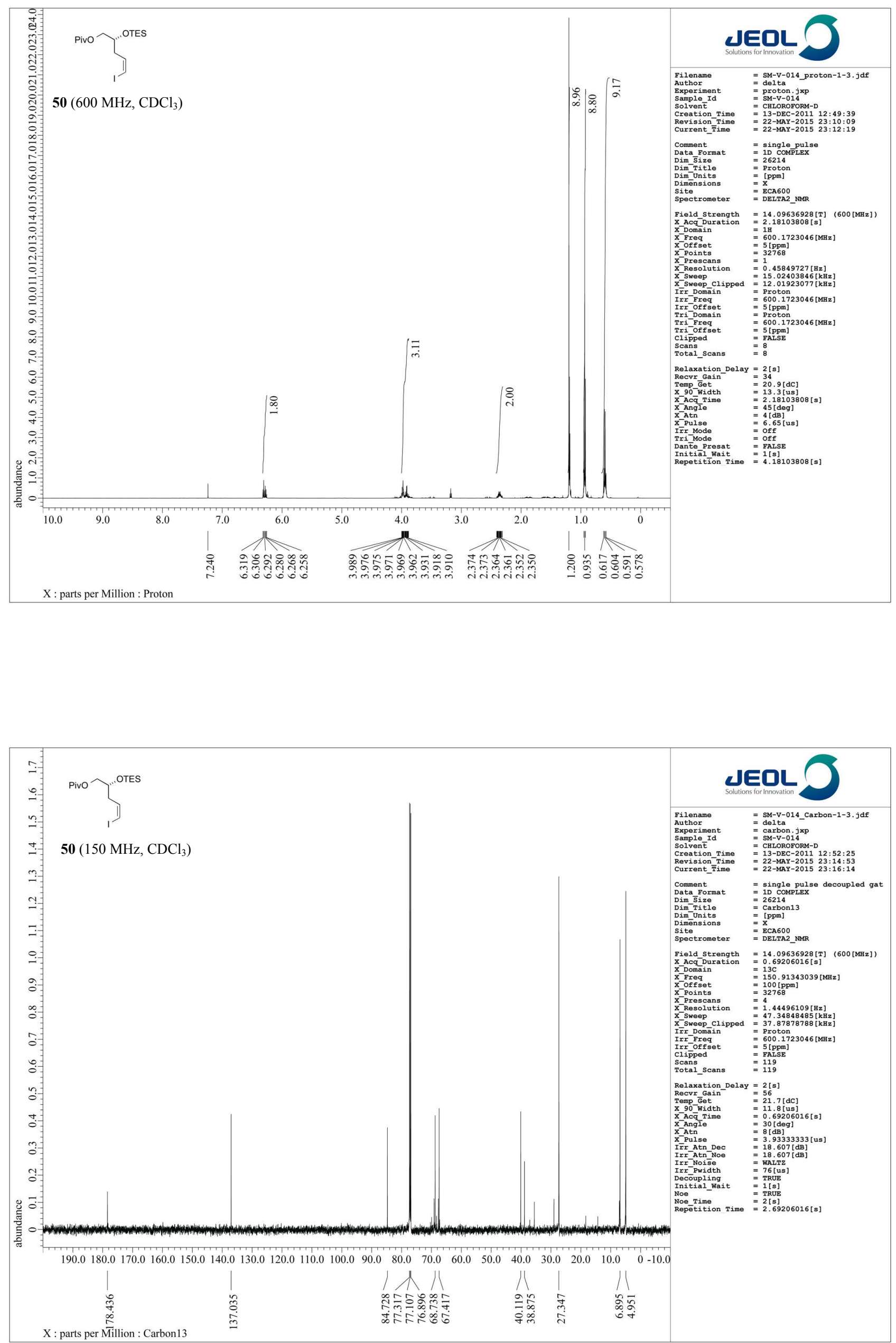

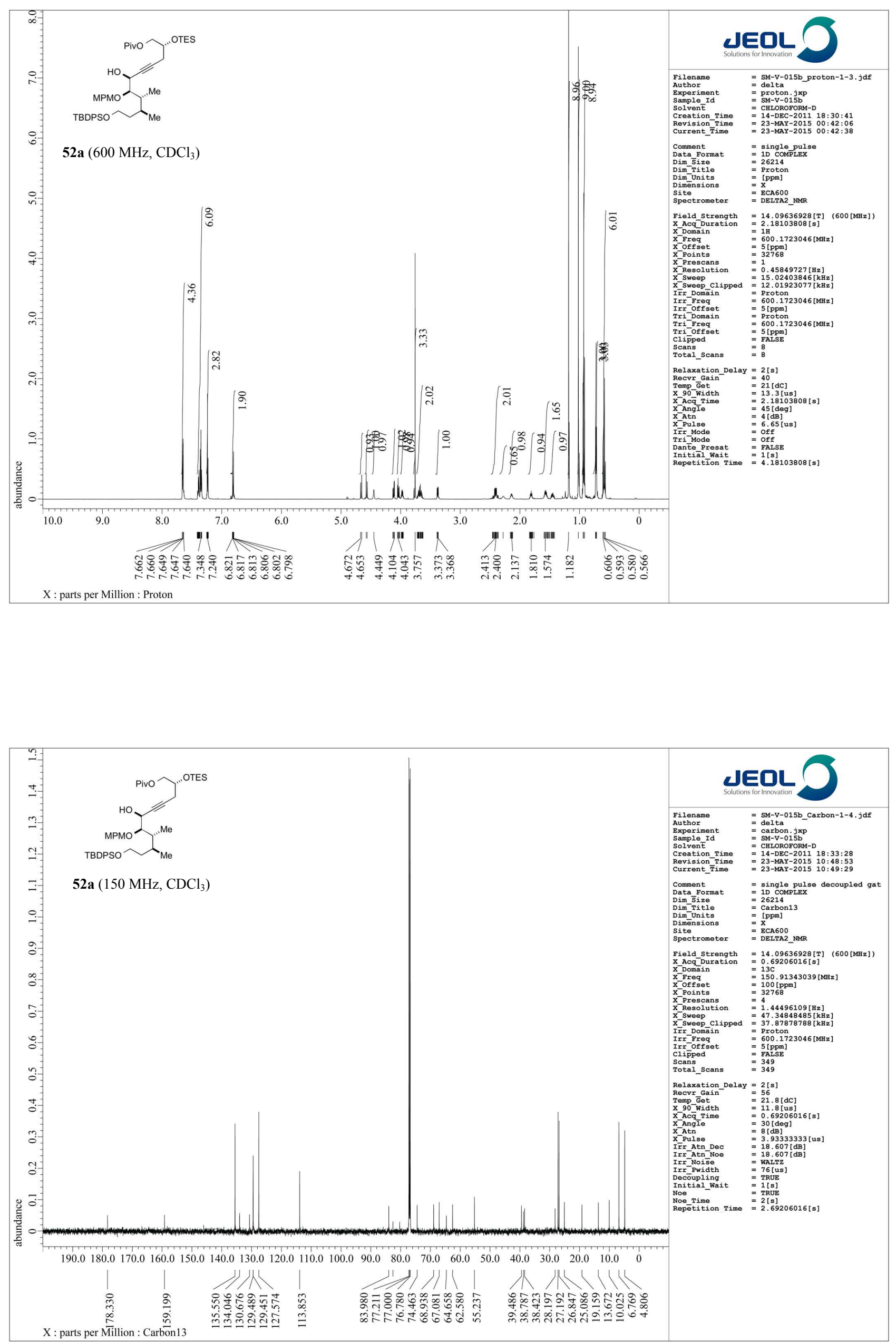

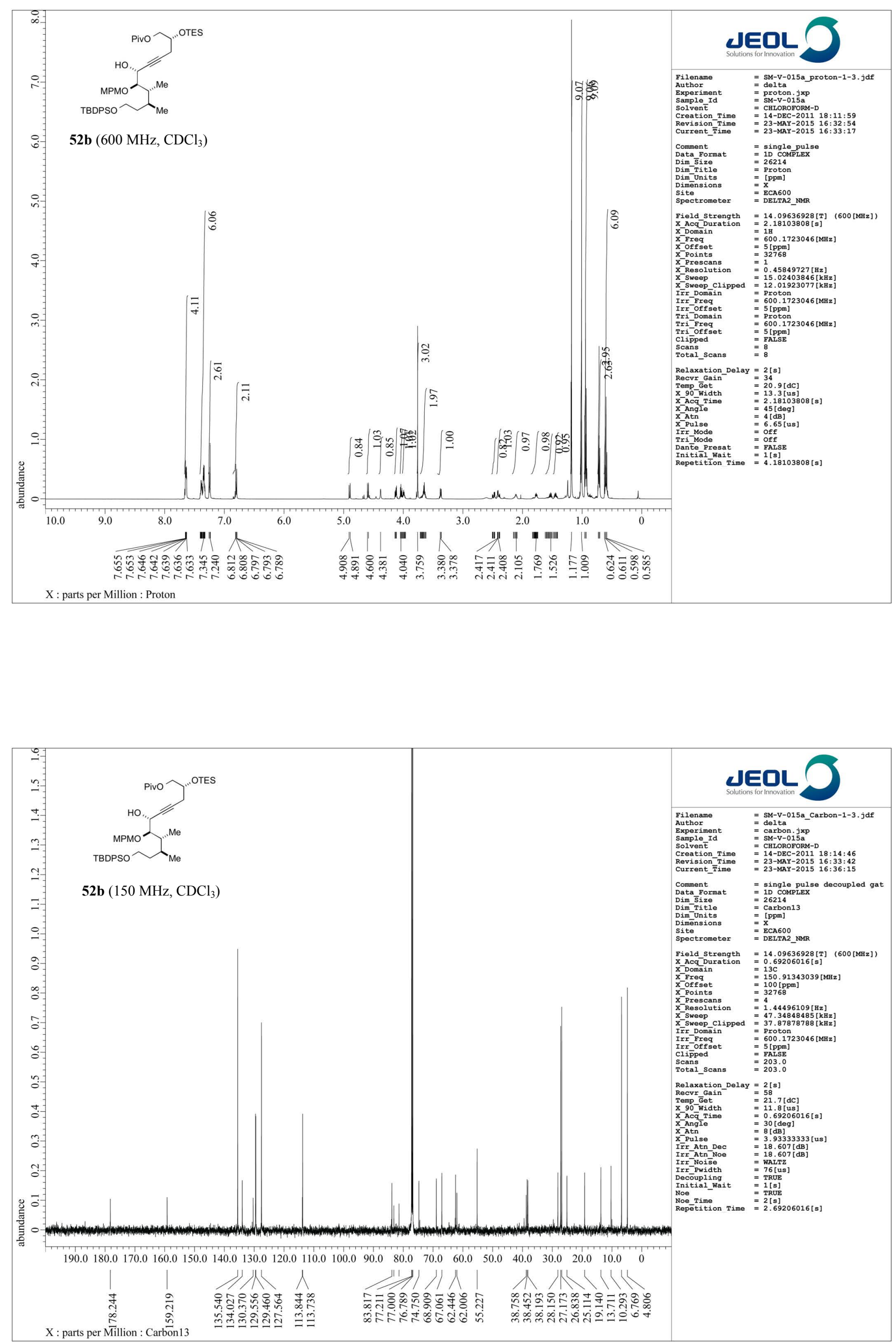

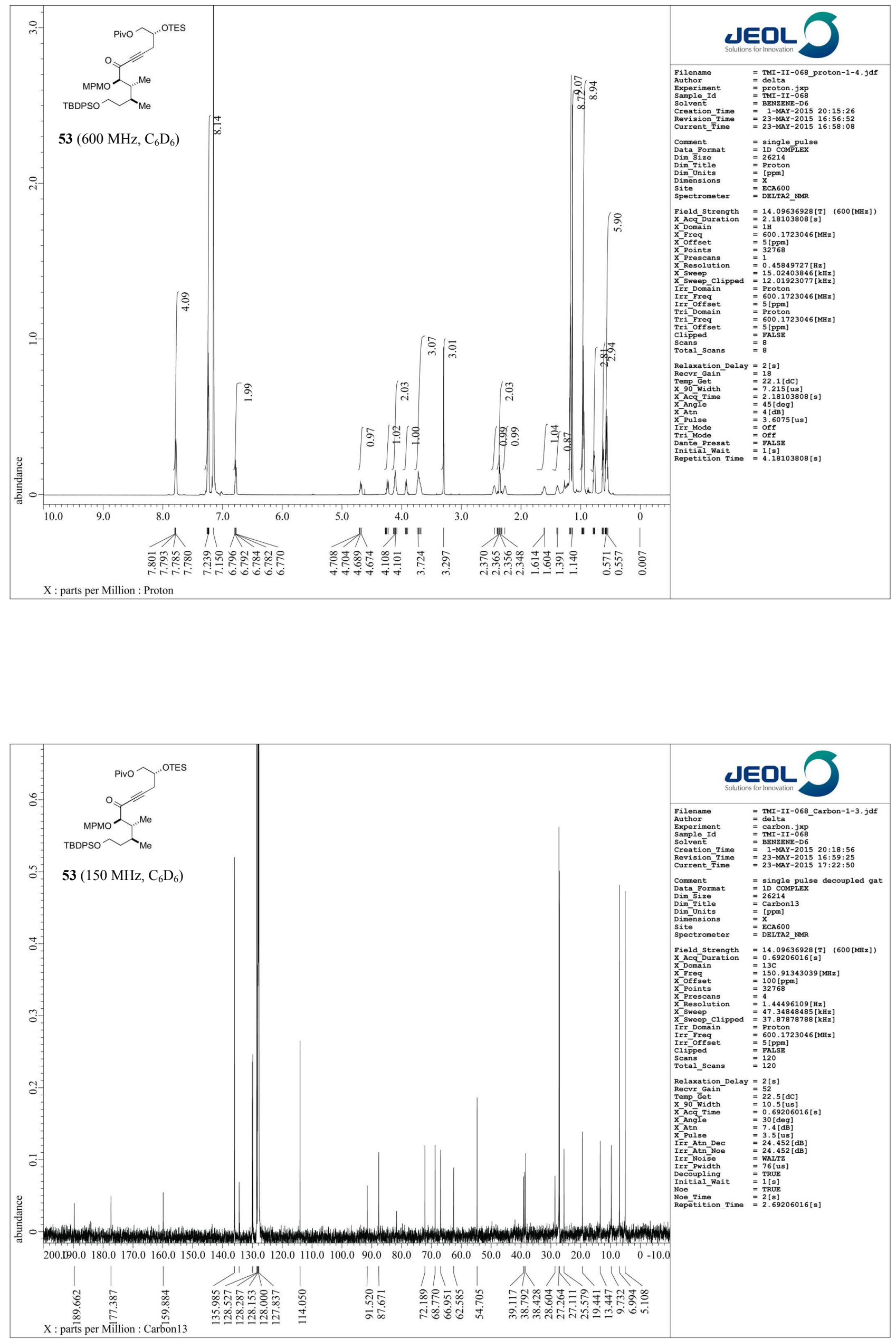

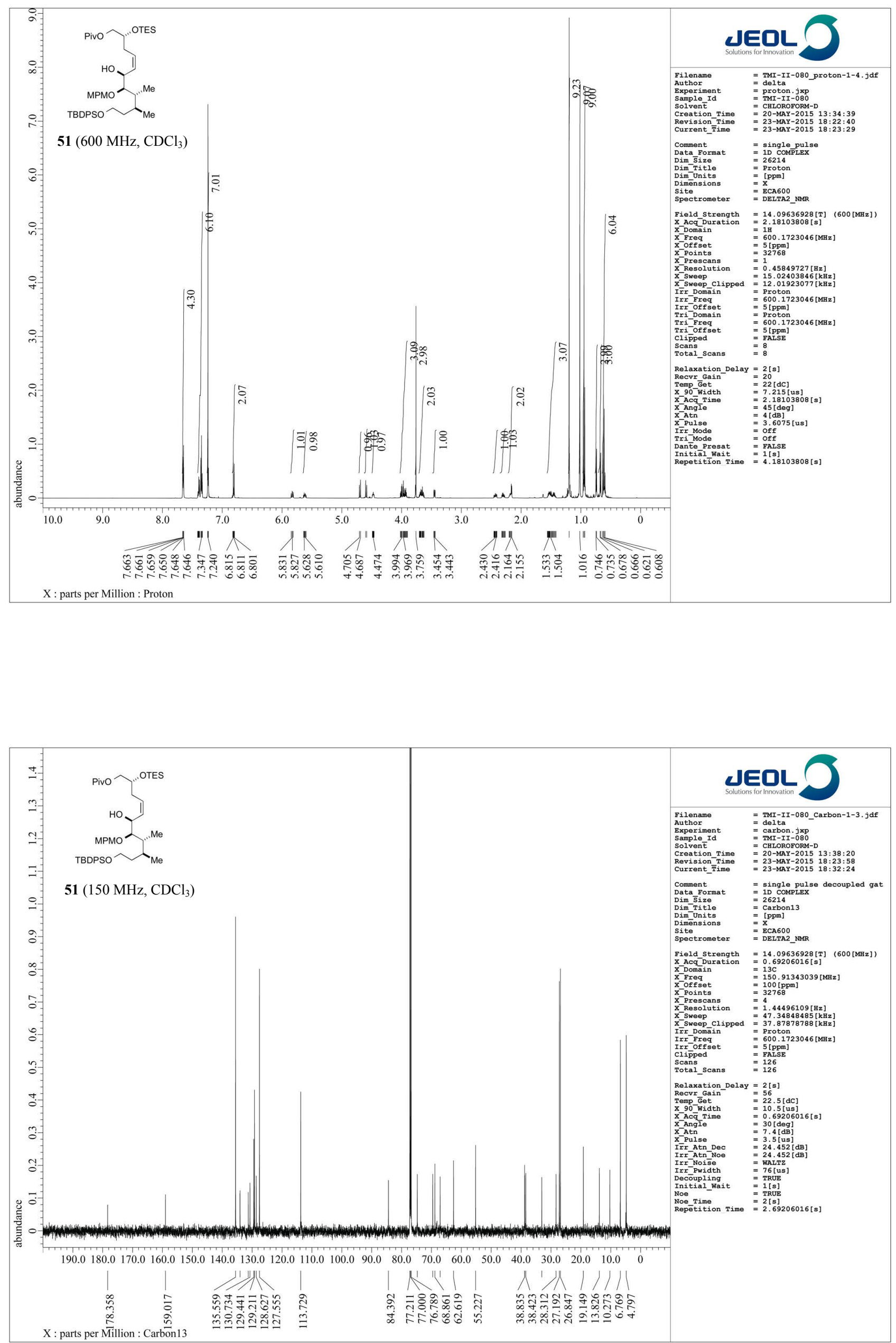

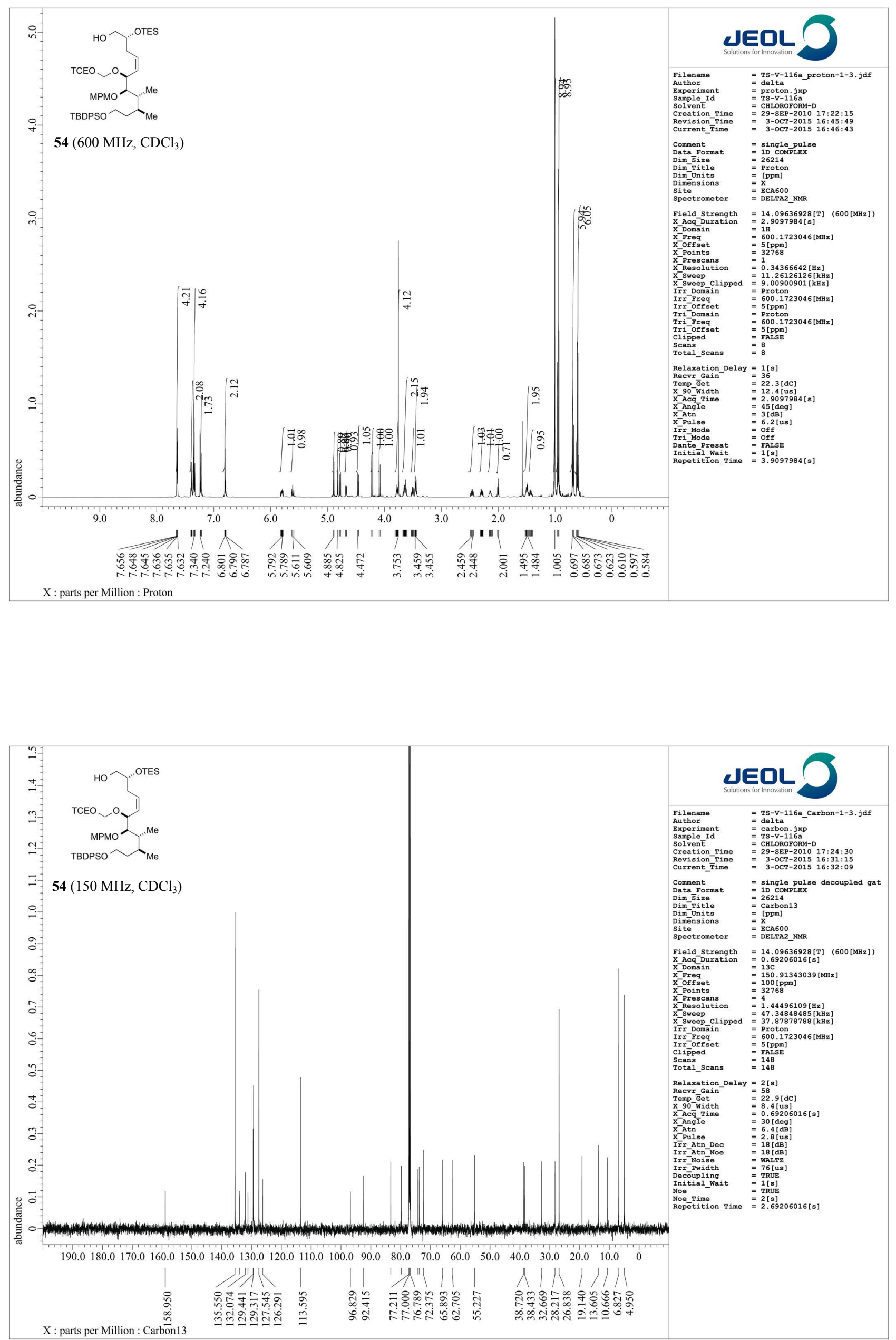

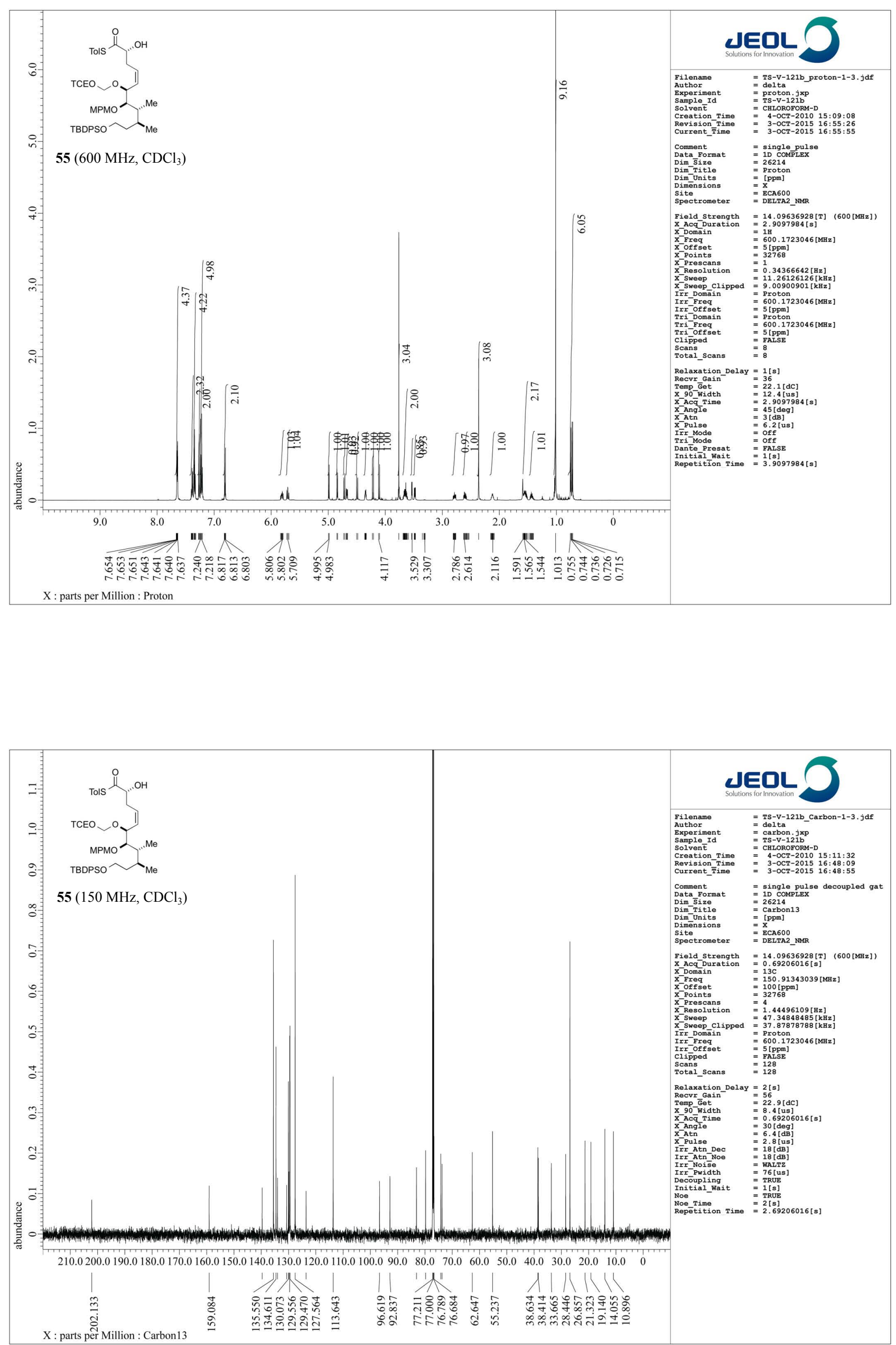

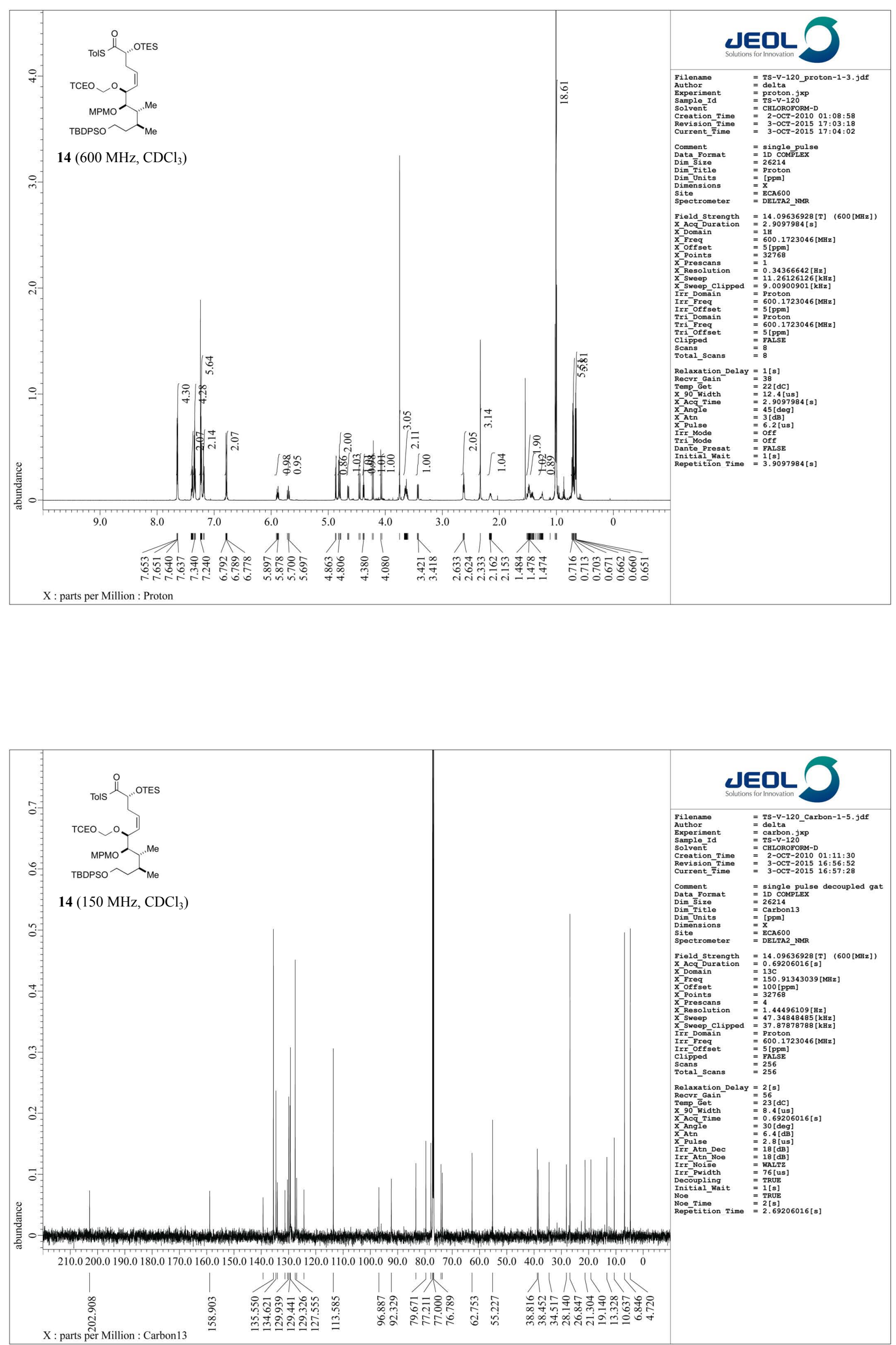

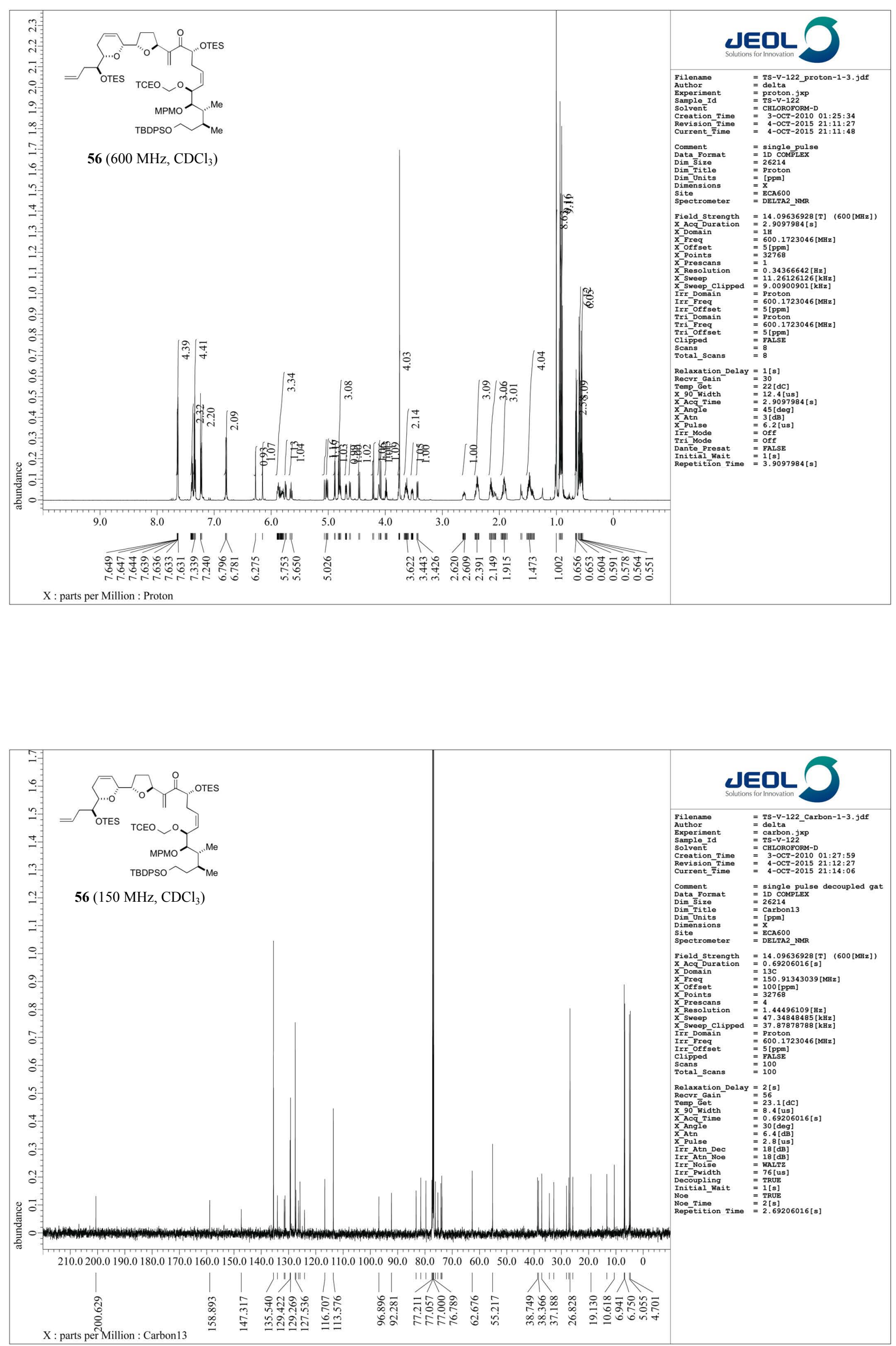

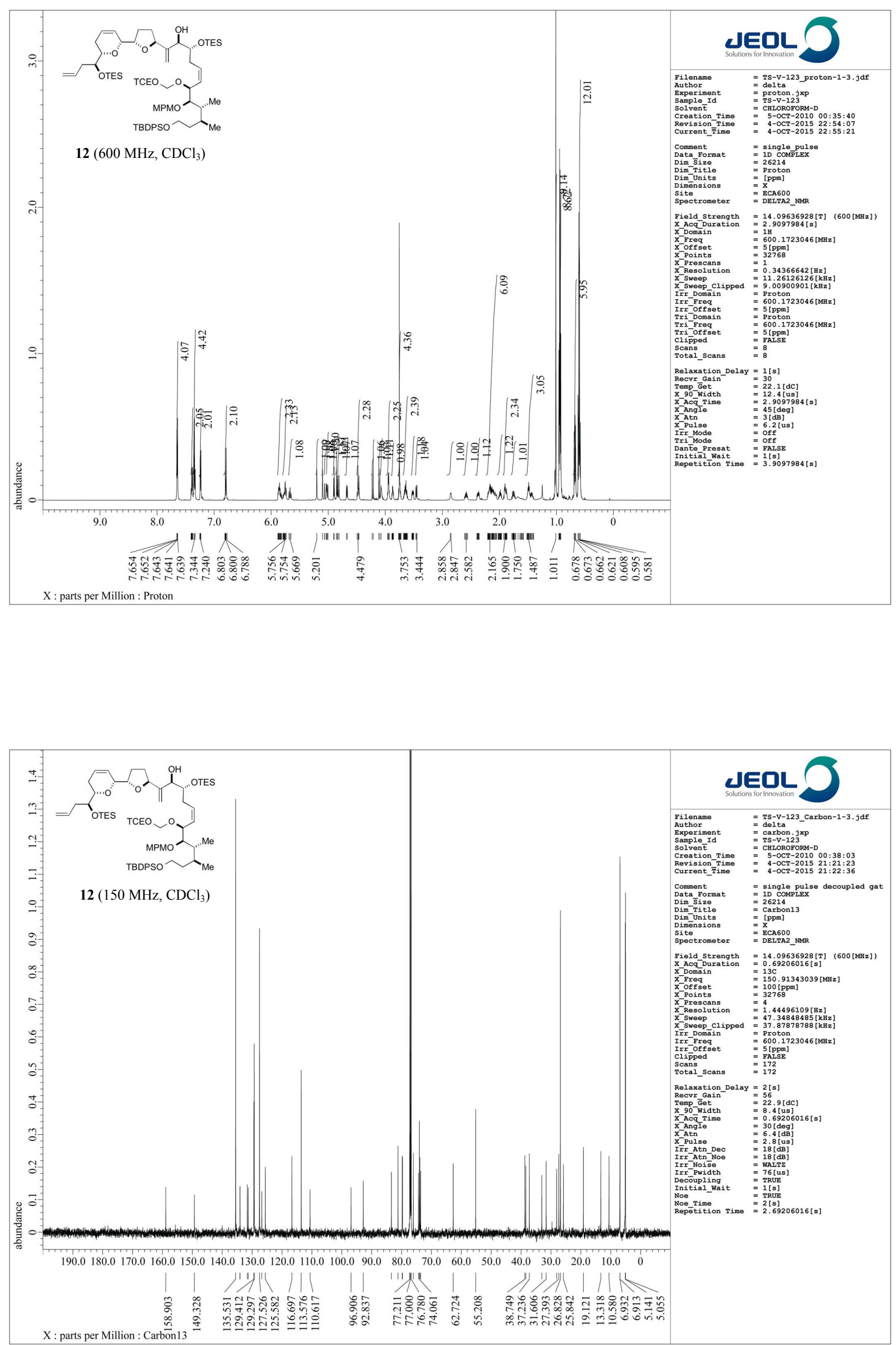

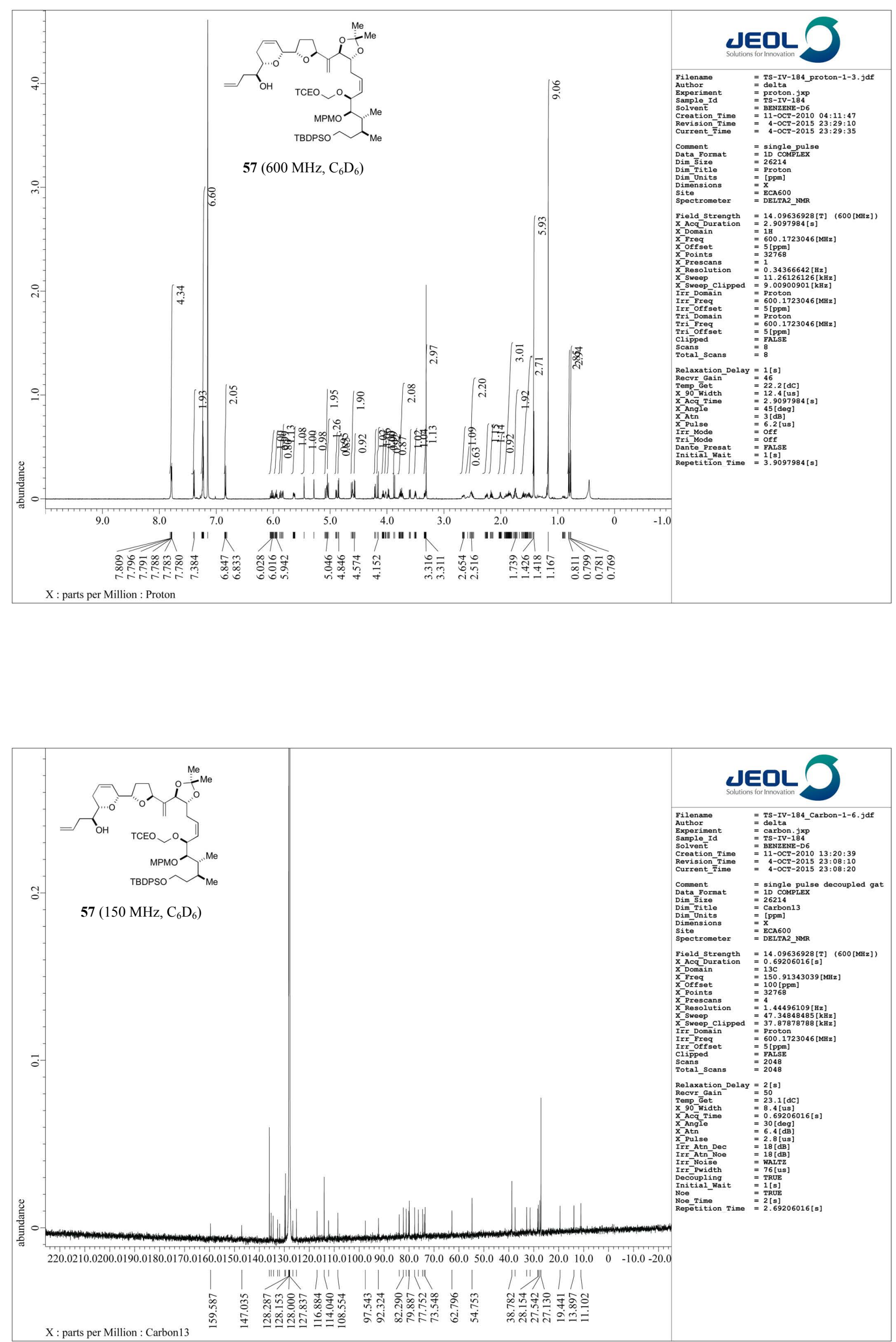